\title{
23. MARINE APTO-ALBIAN PALYNOMORPHS FROM HOLES 400A AND 402A, IPOD LEG 48, NORTHERN BAY OF BISCAY
}

\author{
Roger J. Davey, ${ }^{1}$ Institute of Geological Sciences, Ring Road Halton, Leeds, England ${ }^{2}$
}

\begin{abstract}
Relatively rich marine palynomorph assemblages consisting mainly of dinocysts, but also of microforaminifers and acritarchs, occur throughout the Apto-Albian sequences in Holes 400A and 402A. Of the sporomorphs, bisaccate pollen grains are always abundant and spores are relatively frequent only in Hole 402A. Dating was effected by the comparison of dinocyst distributions here with those in southern England and France. The early-late Aptian boundary is situated between Sections 72-3 and 70-0 in Hole 400A, and near Section 33-6 in Hole 402A. The Apto-Albian boundary is placed immediately above Section 67-0 in Hole 400A and between Sections 26-1 and 25-5 in Hole 402A. Lower Albian was not positively identified and, in Hole 400A, Sections 66-3, 65-2, and probably 64-3 are considered to be of middle Albian age. Only upper Albian was identified above the latter section. The Albian in Hole $402 \mathrm{~A}$ could not be identified above the latter section. The Albian in Hole $402 \mathrm{~A}$ could not be subdivided. Palynomorph distribution indicates that the Apto-Albian in Hole 400A was deposited at a reasonable distance from the landmass and probably not on the continental shelf. In contrast, contemporaneous deposition at Site $402 \mathrm{~A}$ is considered to be nearshore. The characteristics of oceanic and epicontinental assemblages are discussed. The richness of the dinocyst assemblages has necessitated a section on their systematics; three new genera, Bacchidinium, Hapsocysta, and Nexosispinum, and twelve new species, B sarmentum, Codoniella psygma, Gonyaulacysta polythris, $H$. dictyota, $N$. hesperum, Nematosphaerospsis singularis, Oligosphaeridium verrucosum, Ovoidinium diversum, O. implantum, Spiniferites confossus, Surculosphaeridium trunculum, and Systematophora cretacea are proposed.
\end{abstract}

\section{INTRODUCTION}

\section{Hole 400A}

Hole $400 \mathrm{~A}\left(47^{\circ} 22.90^{\prime} \mathrm{N}, 09^{\circ} 11.90^{\prime} \mathrm{W}\right)$ is located at the foot of the Meriadzek Escarpment near the ocean-continent boundary on the northern continental margin of the Bay of Biscay. It is situated about 300 kilometers west of Brest (Brittany) in a water depth of 4399 meters. The top of the Albian was penetrated at 654 meters and the hole terminated at 777.5 meters within the lower Aptian. The Albian is overlain by a thin Campanian-Maestrichtian interval. Cores 62 to 74 were taken in the Apto-Albian sequence, which consists principally of interbedded marly nanno-chalk and sapropelic mudstone; samples from all of these cores, except Core 73 , have been analyzed palynologically.

\section{Hole 402A}

Hole $402 \mathrm{~A}\left(47^{\circ} 52.48^{\prime} \mathrm{N}, 08^{\circ} 50.44^{\prime} \mathrm{W}\right)$ is located on a spur of the northern continental margin of the Bay of Biscay north

\footnotetext{
${ }^{1}$ By permission of the Director, Institute of Geological Sciences, Great Britain.

${ }^{2}$ Present address: Robertson Research International Limited, 'Ty'nY-Coed', Llanrhos, Llandudno, Gywnedd, North Wales, United Kingdom.
}

of the Meriadzek Escarpment in a water depth of 2339.5 meters. It is situated about 320 kilometers west of Brest (Brittany). The top of the Albian was penetrated at 175 meters and the hole terminated at 469.5 meters within the lower Aptian. The Albian is overlain by a middle to upper Eocene interval. Cores 5 to 35 were taken in the Apto-Albian sequence, but, due to poor core recovery, only Cores 11 to 35 have been analyzed palynologically. These cores consist mainly of carbonaceous marly limestones assignable to the "black shale facies."

\section{PALYNOLOGIC RESULTS}

\section{General Discussion}

Emphasis during this study has been on the dinocysts; it is mainly their distributions that have been used in dating, by comparison with known ranges established in accurately dated English and French sections. This information is to be found in the following publications dealing with French Apto-Albian sections: Davey and Verdier, 1971 (Albian), 1973 (upper Albian) and 1974 (Aptian), and Verdier, 1975 (Apto-Albian); and in unpublished research on the AptoAlbian of southern England. Species ranges in Hole 400A (Figure 1) compare well with those in onshore sections but in Hole 402A marker species are rare and ranges are com- 


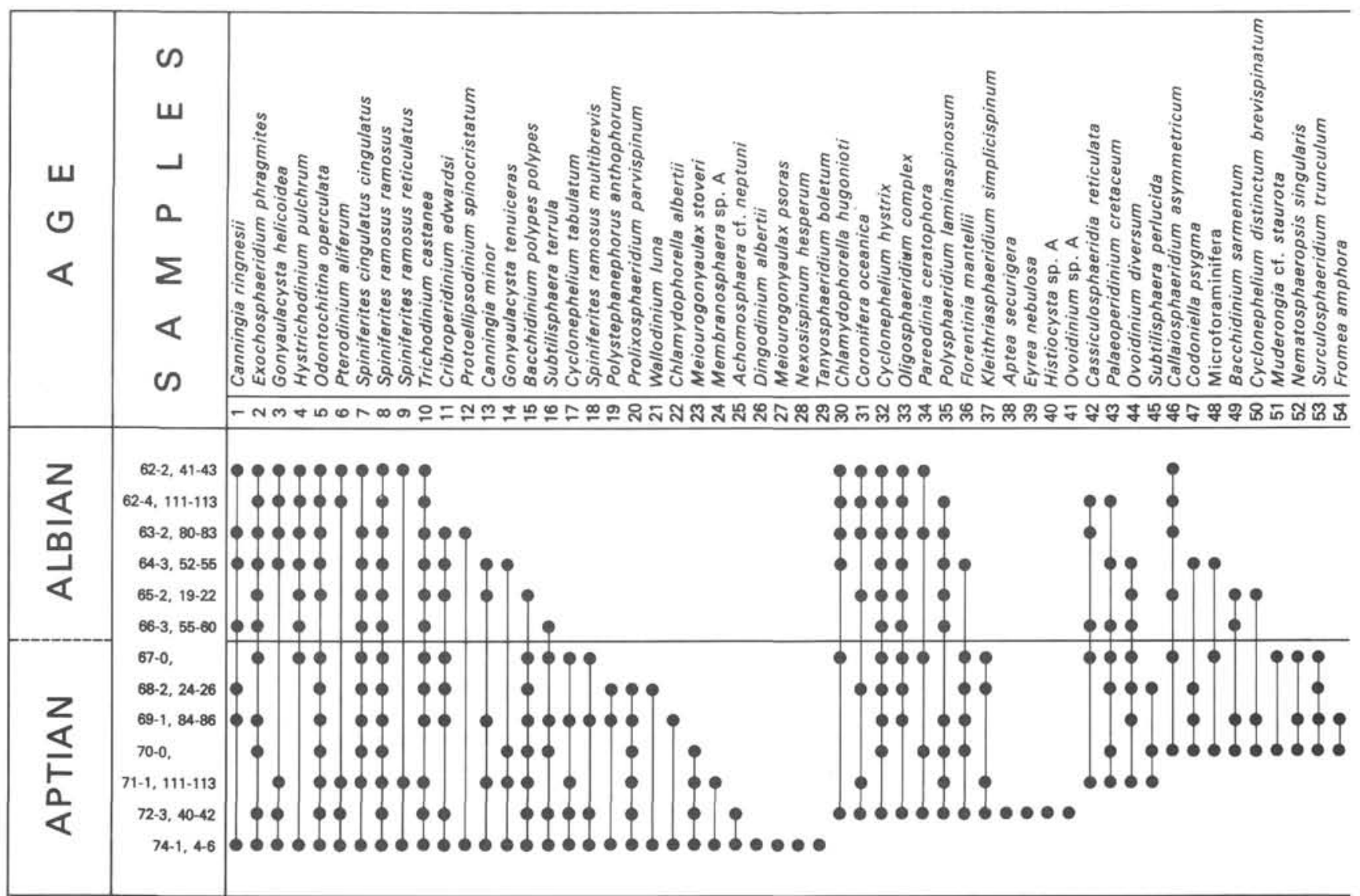

Figure 1. Range-distribution chart of marine palynomorphs in the Apto-Albian at Hole $400 \mathrm{~A}$.

plicated by reworking (Figure 2). Hence the Apto-Albian of Hole $402 \mathrm{~A}$ could only be dated indirectly by comparison with Hole 400A (Figure 3).

Although the majority of dinocyst species recovered at these sites has also been found in England and France, several have been previously recorded in the Apto-Albian of Western Australia. Others are new and are described in the section on systematics. Dating by comparison with results from other parts of the world, for example from Australia (Burger, in press), Canada (Singh, 1964, 1971; Brideaux, 1971a, b; Brideaux and McIntyre, 1975) and offshore South Africa (Davey, in press b), is not possible but does yield important data concerning the geographic distribution of dinocyst species.

\section{Aptian}

Most species in the Aptian at these two sites are either not restricted to this stratigraphic stage, or show somewhat reduced ranges compared with those from the type Aptian (Davey and Verdier, 1974), southern France and southern England (unpublished data).

Chlamydophorella huguonioti (Valensi) occurs but rarely in Hole 400A; its earliest occurrence is in Sample 72-3, 40-42 $\mathrm{cm}$. In southern England it commonly occurs as low as the base of the upper Aptian and in southern France it has a possible record in the upper lower Aptian (Davey and Verdier, 1974). Two stratigraphically important species occur higher in the sequence in Section 70-0, Hole 400A, Meiourogonyaulax stoveri Millioud and Cauca parva Davey and Verdier. In southern England and southern France the former first appears near the base of the upper Aptian whereas the latter first appears in the mid-upper Aptian. Distribution of the three species in Hole 400A indicates that the lower-upper Aptian boundary should be placed tentatively between Section 70-0 and Sample 72-3, 40-42 cm.

They do not occur at this stratigraphic level in Hole 402A, and the Aptian here can only be dated indirectly by comparing distributions of other species with those in Hole 400A (see Figure 3). The correlations are based on the following species: (1) Membranosphaera sp. A, which occurs abundantly in Sample 71-1, 111-113 cm (Hole 400A) and is present in Sample 33-6, 35-38 cm in Hole 402A; (2) Ovoidinium diversum sp. nov., which is abundant in Hole $402 \mathrm{~A}$, first appearing in Sample 32-7, 0-4 cm, whereas it is rare in Hole 400A and first occurs in Sample 71-1, 111-113 $\mathrm{cm}$; and (3) the earliest occurrence of Codoniella psygma sp. nov. and the peak abundance of Oligosphaeridium verrucosum sp. nov. are in Sample 32-7, 0-4 cm in Hole 402A and in Section 70-0 in Hole 400A. The distribution of these species indicates that Sample 33-6, 35-38 cm, Hole 402A must be near the early/late Aptian boundary and that Sample $32-7,0-4 \mathrm{~cm}$, is probably early late Aptian.

\section{Apto-Albian Boundary}

On the evidence discussed below, the Apto-Albian boundary in Hole 400A has been placed above Section 67-0. Sample 400A-68-2, 24-26 cm, contains the youngest strati- 


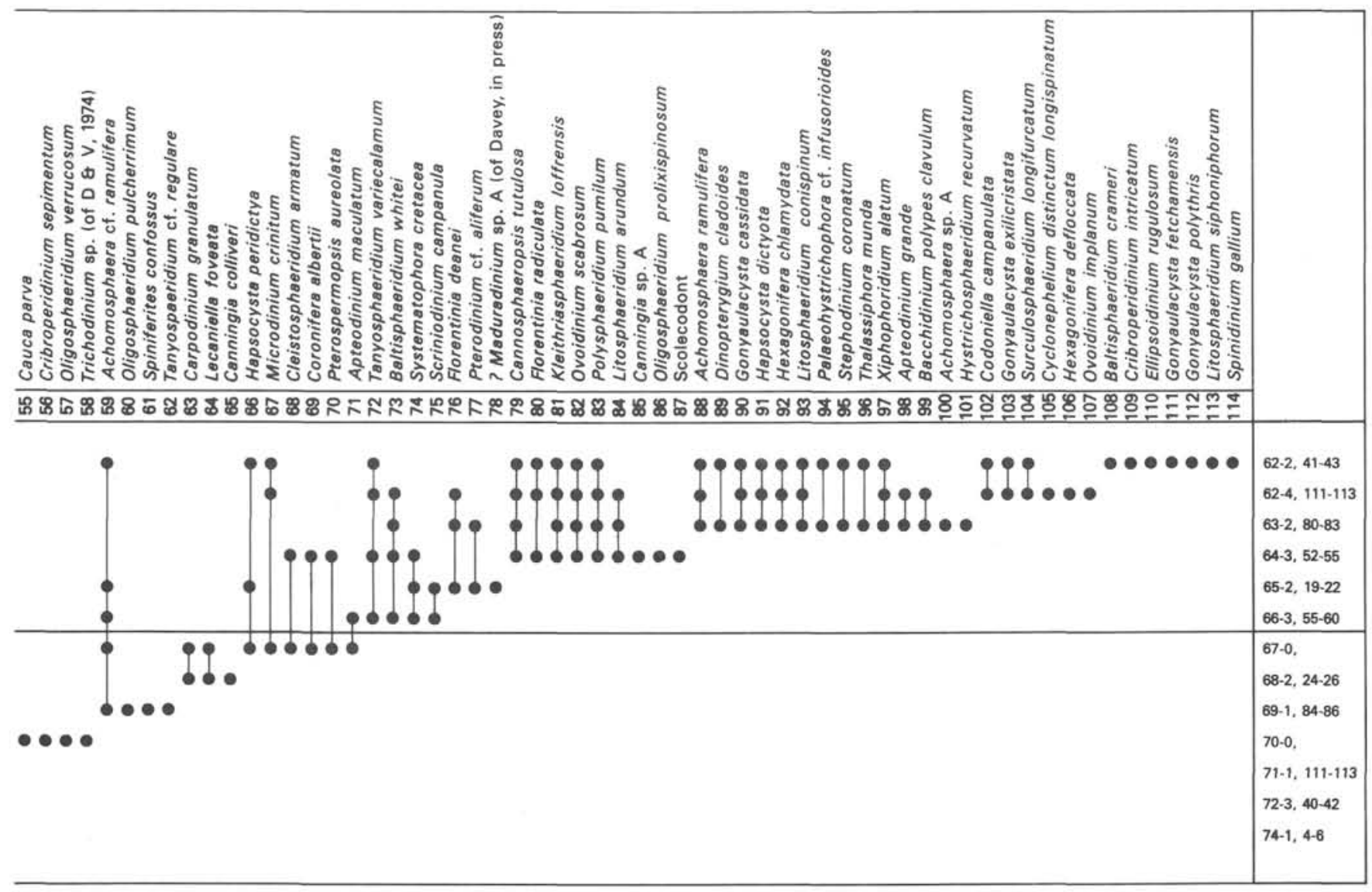

Figure 1. (Continued).

graphic occurrence of two species most commonly restricted to pre-Albian strata. Polystephanephorus anthophorum (Cookson and Eisenack) has an uppermost occurrence in the upper Aptian (upper Gargasian) of southern France (Davey and Verdier, 1974), in the uppermost Aptian (H. jacobi Zone) of southern England, in the lower Albian (D. mammillatum Zone) of northern France (Verdier, 1975), and in the upper middle Albian of Germany (Dörhöfer, personal communication). In Canada, although it was recorded only from the Aptian by Brideaux and McIntyre (1975), in other localities it ranges into the middle and upper Albian (Davey, 1969a; Brideaux, 1971; Singh, 1971). This extended range into the Albian of Canada, Germany, and northern France indicates that the temporal range of $P$. anthophorum was either climatically controlled or that, in those sections, it has been reworked. The former explanation is favored by Dörhöfer (personal communication) who regards the species as a cold water form characteristic of the subarctic water mass. In Hole 402A it occurs to the top of the Albian (Sample $11-4,105-108 \mathrm{~cm}$ ) and, in this case, is regarded as being reworked because of association with other reworked species in this section. Thus, on the evidence from southern England and southern France and its absence from the Albian of the Paris Basin, (Davey and Verdier, 1971), at this latitude the youngest occurrence of $P$. anthophorum is regarded as topmost Aptian. The second species, Subtilisphaera perlucida (Alberti), has a youngest recorded occurrence in the upper Aptian (mid-Gargasian) of southern France (Davey and Ver- dier, 1974) and in the upper Aptian (H. jacobi Zone) of southern England.

In Section 67-0, Hole 400A, is the last occurrence of three species restricted to pre-Albian strata. The uppermost limit for Muderongia cf. staurota Sarjeant of Davey and Verdier (1974) is in the upper lower Aptian (upper Bedoulian) of southern France, in the uppermost Aptian ( $H$. jacobi Zone) of southern England, and in the upper Aptian at Site 361, DSDP Leg 40 (Davey, in press b). For Cyclonephelium tabulatum Davey and Verdier it is the uppermost Aptian of southern France (Davey and Verdier, 1974), northern France (Verdier, 1975), and in the $H$. jacobi Zone of southern England, and for Surculosphaeridium trunculum sp. nov. it is in the H. jacobi Zone of southern England.

The Apto-Albian boundary in Hole 400A is based thus on the last occurrence of the above forms. Although these species occur in Hole 402A, they cannot there be used for dating because of extensive reworking. In their stead, first stratigraphic occurrence of Hapsocysta peridictya (Eisenack and Cookson) comb. nov. in Sample 26-1, 9-14 cm, Hole $402 \mathrm{~A}$ is the defined marker species. It occurs also in Section $67-0$, Hole 400A. On this basis the Apto-Albian boundary in Hole 402A is tentatively placed above Section 26-1, which position is substantiated by the first stratigraphic occurrence of Lecaniella foveata Singh in Sample 30-6, 60-63 cm, Hole $402 \mathrm{~A}$, and in Sample 68-2, 24-26 cm, Hole 400A; in southern England it first appears in the uppermost Aptian $(H$. jacobi Zone). 




Figure 2. Range-distribution chart of marine palynomorphs in the Apto-Albian at Hole $402 \mathrm{~A}$.

\section{Albian}

Most of the species in the lower Albian in Hole 400A are not stratigraphically restricted to this stage and the two species Litosphaeridium arundum (Eisenack and Cookson) comb. nov. and Microdinium setosum Sarjeant that elsewhere first appear in the lower Albian do not occur until higher in the $400 \mathrm{~A}$ sequence. Systematophora cretacea sp. nov. occurs in Samples 66-3, 55-60 cm; 65-2, $19-22 \mathrm{~cm}$; and $64-3,52-55 \mathrm{~cm}$. Previously it has been recorded from the lower middle Albian (H. dentatus Zone) of France (Davey and Verdier, 1971) and southern England, and from the upper middle Albian (E. lautus Zone), and upper Albian (D. cristatum and $M$. inflatum zones) of northern France (Verdier, 1975). The latter isolated occurrence in the $M$. inflatum Zone is not considered significant; $S$. cretacea is probably 


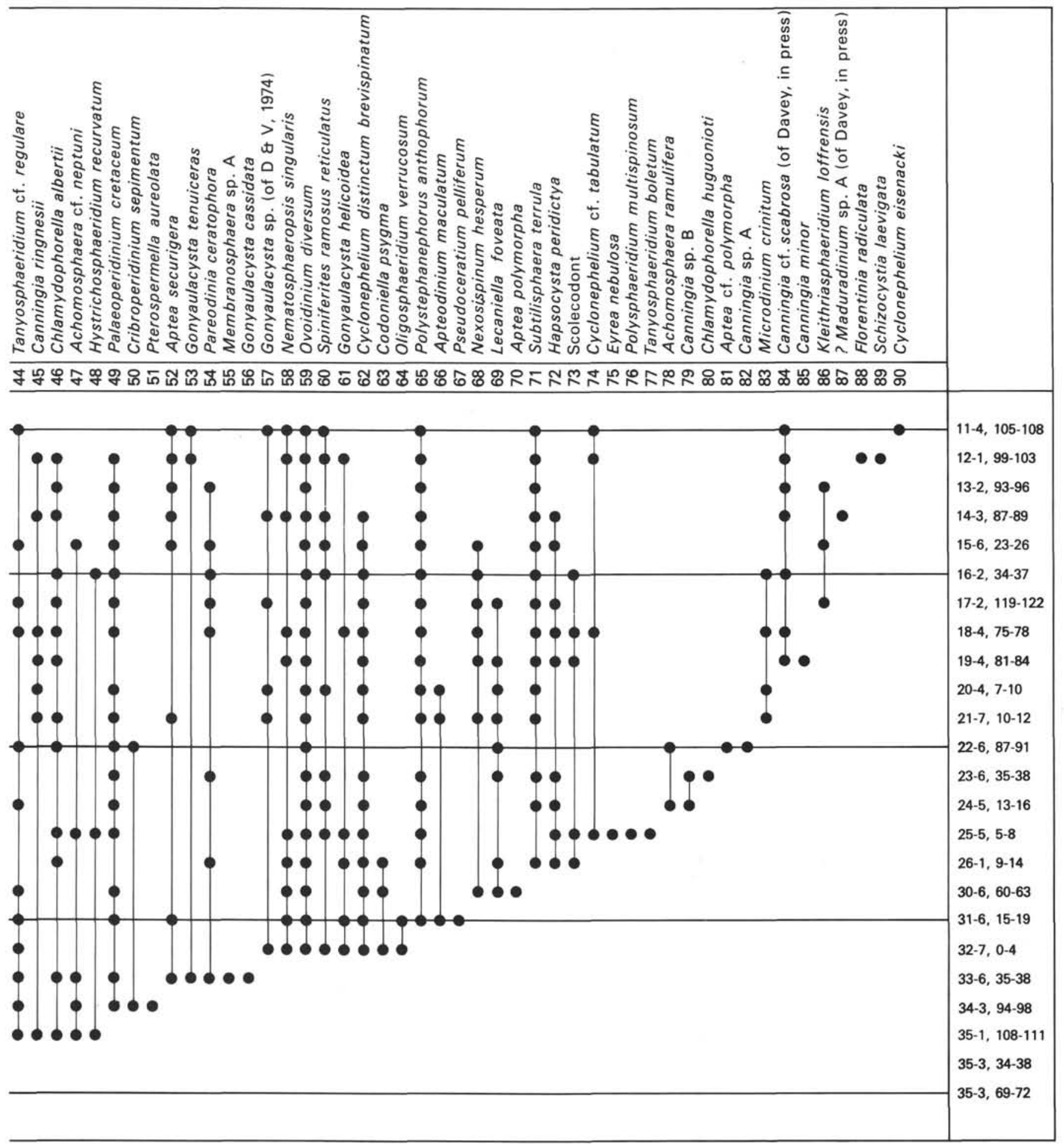

Figure 2. (Continued).

mainly a middle Albian species which may range up into the D. cristatum Zone. Sections 66-3 and 65-2 are hence of middle Albian age and Section 64-3 is probably situated near to the middle-late Albian boundary.

Higher in the sequence in Hole 400A, Sample 63-2, 80-83 $\mathrm{cm}$ contains the first stratigraphic appearance of several forms:

1) Apteodinium grande Cookson and Hughes which first occurs near the top of the $M$. inflatum Zone in southern England and within this zone in France (Davey and Verdier, 1971, 1973; Verdier, 1975);

2) Hexagonifera chlamydata Cookson and Eisenack which first appears within the $M$. inflatum Zone in southern England and France (Davey and Verdier, 1971, 1973; Verdier, 1975); 3) Litosphaeridium conispinum Davey and Verdier which is restricted to the $M$. inflatum Zone in southern England and 


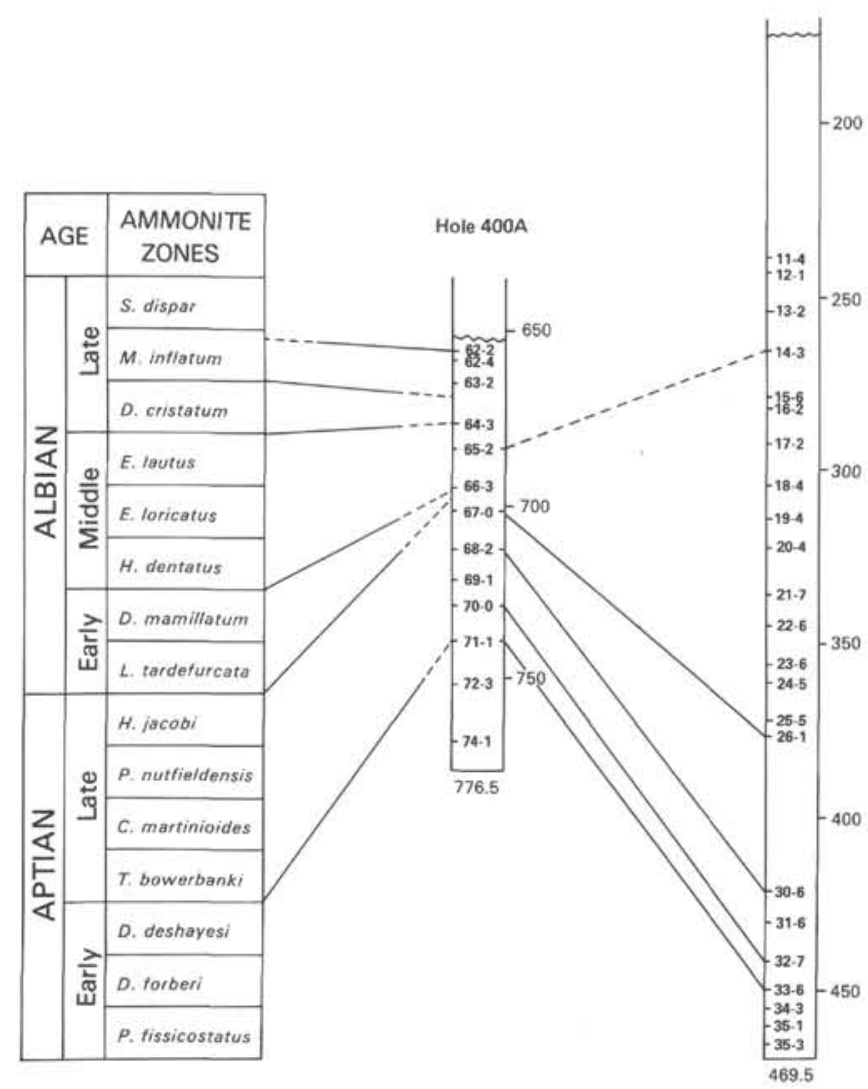

Figure 3. Dating of the Apto-Albian sequence at Hole $400 \mathrm{~A}$ and its correlation to Hole 402A. (Dashed lines indicate tentative correlations.)

France (Davey and Verdier, 1975).

4) Palaeohystrichophora $\mathrm{cf}$. infusorioides Deflandre of Davey and Verdier (1973) at the base of the $M$. inflatum Zone in southern England and France (Davey and Verdier, 1973); and

5) Thalassiphora munda Davey and Verdier, first occurs in the $M$. inflatum Zone of France (Davey and Verdier, 1973; Verdier, 1975).

In addition, Protoellipsodinium spinochristatum Davey and Verdier has a last occurence in the same sample and in the $M$. inflatum Zone in England and France (Davey and Verdier, 1971; Verdier, 1975). Thus Sample 63-2, 80-83 cm is undoubtedly assignable to the $M$. inflatum Zone.

Sample $62-4,111-113 \mathrm{~cm}$, also belongs to the $M$. inflatum Zone because it contains the highest stratigraphic occurrence of Litosphaeridium arundum (Eisenack and Cookson) comb. nov. which in England and in France (Davey and Verdier, 1971) does not range higher than this zone.

The topmost sample $(62-2,41-43 \mathrm{~cm})$ examined from Site $400 \mathrm{~A}$ is assignable to the upper part of the $M$. inflatum Zone because it contains both Litosphaeridium siphoniphorum (Cookson and Eisenack) and L. conispinum (see Davey and Verdier, 1973).

Unfortunately none of the above stratigraphically restricted Albian species occur in Hole 402A. The only noteworthy occurrence is that of ?Maduradinium sp. A of Davey (in press b) in Sample 14-3, $87-89 \mathrm{~cm}$. It also occurs in Sample 65-2, 19-22 cm, Hole 400A, in the middle Albian of England, in the Upper Cretaceous of Australia (as ?Meiourogonyaulax sp. A of Norvick and Burger, 1976), at Site 361 (DSDP Leg 40) (Davey, in press b) and in France (unpublished data). The suggested site correlation must be regarded as most tenuous.

\section{Dinocyst Distribution}

The dinocyst assemblages from the Apto-Albian of Holes $400 \mathrm{~A}$ and $402 \mathrm{~A}$ compare most closely with those of similar age from southern England and the Paris Basin. This is not surprising considering the distance $(600-1000 \mathrm{~km})$ separating the sites from those onshore. In addition, deposition in each case must have been at a similar paleolatitude, approximately $30^{\circ} \mathrm{N}$ (Smith et al., 1973). Species differences in Hole $400 \mathrm{~A}$ can be attributed to the bathyal water depth at that site and distance from shore, but at Site 402 deposition took place in a shallow water, nearshore environment comparable to that in southern England and the Paris Basin. Other factors must have been responsible for the differences in species occurrence and abundance.

Several of the species that occur consistently, and often abundantly, in the Apto-Albian of southern England and the Paris Basin either do not occur in Holes 400A and 402A or are very rare. These include Apteodinium granulatum Eisenack, 1958, Cauca parva (Alberti), Dingodinium albertii Sarjeant, Florentinia laciniata Davey and Verdier, $F$. radiculata (Davey and Williams), Gonyaulacysta tenuiceras (Eisenack), Litosphaeridium arundum (Eisenack and Cookson), Microdinium? crinitum Davey, Ovoidinium verrucosum (Cookson and Hughes) Davey, 1970, Protoellipsodinium spinocristatum Davey and Verdier and Scriniodinium campanula Gocht. Conversely certain species only occur in the Biscay holes, namely Bacchidinium sarmentum sp. nov., Codoniella companulata (Cookson and Eisenack), C. psygma sp. nov., Gonyaulacysta polythris sp. nov., Hapsocysta dictyota sp. nov., H. peridictya, Nematosphaeropsis singularis $\mathrm{sp}$. nov. Hexosispinum hesperum $\mathrm{sp}$. nov., Ovoidinium implanum sp. nov., and Spiniferites confossus sp. no. $C$. campanulata and $H$. peridictya have been previously recorded only from Western Australia; a third Western Australian species, Cannosphaeropsis tutulosa Cookson and Eisenack has been only observed once in southern England. Probable examples of $C$. psygma, reported as Hystrichosphaeropsis ovum by Habib (1972) occur in the Apto-Albian of the western North Atlantic (Leg 11, DSDP).

Morphologically, the genera Cannosphaeropsis O. Wetzel, 1933b, Codoniella Cookson and Eisenack, 1961a, and Hapsocysta gen. nov. have in common extensive periphragm structures which aid flotation and are considered to be oceanic adaptations. A comparable example of this adaptation is seen in Nematosphaeropsis labyrinthea (Ostenfeld) Reid, 1974, which is characteristic of the North Atlantic. The virtual absence of these genera from the Apto-Albian epicontinental seas of southern England, the Paris Basin, southern France, Canada, and Queensland, Australia (Burger, in press) substantiates this conclusion.

Thus, during the Apto-Albian, Sites 400 and 402 had an oceanic geographic setting whereas, in southern England and the Paris Basin, sediments accumulated in epicontinental seas covering extensive shelf areas. However, significant differences exist between the dinocyst assemblages at the two 
sites, mainly because of their different distances from land and perhaps different water depths. Although species content and number of species per sample of the two sites is similar (except in the middle and upper Albian which, in part at least, is not present at Hole 402A), the relative abundance of species and groups of species differ albeit that reworking cannot be assessed in the upper part of Hole 402A. In general, chorate cyst genera such as Bacchidinium gen. nov., Cyclonephelium Deflandre and Cookson, 1955, Oligosphaeridium Davey and Williams, 1966b, Spiniferites Mantell, 1850, and Surculosphaeridium Davey et al., 1966, comprise more than 50 per cent of all assemblages. In Hole 402 A the peridinacean cysts Subtilisphaera Jain and Millepied, 1973, and Ovoidinium diversum sp. nov. are also consistently abundant whereas in Hole 400A they are uncommon. In contrast, in Hole $400 \mathrm{~A}$, moderate sized proximate cysts of the Pterodinium-Leptodinium group and Spiniferites cingulatus $(\mathrm{O}$. Wetzel) are often abundant particularly in Cores 68 to 74 . Increased abundance of peridinacean cysts is a well-established nearshore phenomenon reported by, amongst others, Davey (1970) in the Cenomanian, Harland (1971) in the Campanian, and in Recent sediments by Harada (1974, unpublished) and Harland (in press). At the present day, however, Leptodinium Klement, 1960, is rare or absent in shelf sediments (Reid and Harland, in press), and becomes abundant only in offshore, deeper water (oceanic) deposits (Wall and Dale, 1967; Davey and Rogers, 1975). An alternative explanation of the differences may be that Site 402 had been affected by a relatively cold current (Dörhöfer, personal communication).

Ovoidinium diversum is another form that appears to be almost restricted to an oceanic, rather than an epicontinental, nearshore environment. It has not been recorded from the Paris Basin and has been recorded only once in southern England. $O$. indistinctum (Cookson and Eisenack) (Lentin and Williams, 1975) which is rather similar to $O$. diversum also has been recorded only from the oceanic Apto-Albian sediments of Western Australia.

Two other genera may be indexes of depositional environment. Lecaniella Cookson and Eisenack (1962) occurs rarely in Sections 17-2, 19-4, 20-4, 21-7, 22-6, 23-6, 26-1, and 30-6 in Hole $402 \mathrm{~A}$ and in $67-0$ and $68-2$ at Hole $400 \mathrm{~A}$. The Hole $400 \mathrm{~A}$ occurrences are in sapropelic mudstones and are probably the result of down-slope contamination rather than in place occurrences. Schizocystia Cookson and Eisenack (1962a) was found only in Section 12-1, Hole 402A. In southern England, Lecaniella is well represented in the uppermost Aptian (H.jacobi Zone) and Schizocystia has a single occurrence in the lower upper Aptian $(C$. martiniodes Zone). However, these two genera have been found, sometimes abundantly, in some southwest England (Institute of Geological Sciences) off shore boreholes (SLS 64, Lizard; SLS 28 and 72, Haig Fras; SLS 74, Scilly). The palynologic assemblages containing these genera are dominated by terrestrial plant debris and sporomorphs and in these respects closely resemble the Hole $402 \mathrm{~A}$ assemblages. The only other localities where Lecaniella and Schizocystia are known to occur abundantly are in the Albian of northwest Alberta, Canada (Singh, 1971) and the Apto-Albian of Australia (Cookson and Eisenack, 1962a). Lecaniella has been also recorded from the District of Mackenzie, Canada, by
Brideaux and McIntyre (1975). Neither genus has been reported from the Paris Basin (Davey and Verdier, 1974), the Grand Banks (Williams and Brideaux, 1975), or Queensland, Australia (Burger, in press). The known distribution of Lecaniella and Schizocystia suggest that they prefer a nearshore, oceanic environment in northwest Europe.

\section{SYSTEMATIC DESCRIPTIONS}

The following section is divided into two parts. The first lists, in alphabetical order, all marine palynomorph species encountered during this study and indicates, where appropriate, the plates on which they are figured. Figures in the square brackets refer to the position of that species on Figures 1 and 2, i.e. [25] [47] indicates that this species is number 25 on Figure 1 and number 47 on Figure 2. New species or those that require certain amplifying remarks are indicated by an asterisk (*) and are dealt with in the second part. All type material and figured specimens have been assigned MPK numbers and are housed in the palynologic slide collection at the Institute of Geological Sciences, Leeds.

\section{Palynomorph Species}

Achomosphaera cf. neptuni (Eisenack, 1958) Davey and Williams, 1966a, in Davey and Verdier, 1974. (Plate 1, Figures 2, 3). [25] [47].

A. ramulifera (Deflandre, 1937b) Evitt, 1963. [88]- .

*A. cf. ramulifera (Deflandre, 1937b) Evitt, 1963. (Plate 1, Figure 1). [59] [78].

*Achomosphaera sp. A. (Plate 1, Figures 4-6). [100]-.

Apteodinium grande Cookson and Hughes, 1964. [98]-

A. maculatum Eisenack and Cookson, 1960. [71] [66].

Aptea polymorpha Eisenack, 1958. - [70].

A. cf. polymorpha Eisenack, 1958. -[81].

A. securigera Davey and Verdier, 1974. [38] [52].

*Bacchidinium polypes polypes (Cookson and Eisenack, 1962b) comb. nov. (Plate 1, Figure 7). [15] [31].

B. cf. polypes polypes (Cookson and Eisenack, 1962b) comb. nov. [34].

B. polypes (Cookson and Eisenack, 1962b) comb. nov. subsp. clavatum Davey, 1969a. [99] -.

*B. sarmentum sp. nov. (Plate 1, Figures 8-12). [49] -,

Baltisphaeridium whitei Deflandre and Courteville, 1939. [73] [24].

B. crameri Singh, 1971. (Plate 1, Figure 13). [108] [20].

Callaiosphaeridium asymmetricum (Deflandre and Courteville, 1939) Davey and Williams, 1966b. (Plate 2, Figure 1). [46] [1].

Canningia colliveri Cookson and Eisenack, 1960b. [65] -

C. minor Cookson and Hughes, 1964. [13] [85].

C. ringnesii Manum and Cookson, 1964. (Plate 2, Figure 4). [1] [45].

C. cf. ringnesii Manum and Cookson, 1964. - [37].

C. cf. scabrosa Cookson and Eisenack, 1970a, of Davey, in press b. - [84].

*Canningia sp. A. (Plate 3, Figure 4). [85] [82].

*Canningia sp. B. (Plate 1, Figures 14, 15). - [79].

${ }^{*}$ Cannosphaeropsis tutulosa Cookson and Eisenack, 1960a. Plate 2, Fig. ures 5-7). [79]-.

Carpodinium granulatum Cookson and Eisenack, 1962b. [63] -

Cassiculosphaeridia reticulata Davey, 1969a. (Plate 2, Figure 3). [42] [30].

Cauca parva (Alberti, 1961) Davey and Verdier, 1971. [55] -

Chlamydophorella albertii (Neale and Sarjeant, 1962) Davey, in press b. [22] [46].

C. huguonioti (Valensi, 1955a) Davey, in press b. (Plate 4, Figure 18). [30] [80].

Cleistosphaeridium armatum (Deflandre, 1937b) Davey, 1969a. [68] [42].

*Codoniella campanulata (Cookson and Eisenack, 1960a) Downie and Sarjeant, 1964. (Plate 2, Figure 8). [102] -.

${ }^{*} C$. psygma sp. nov. (Plate 2, Figures 9-14). [47] [63].

Coronifera albertii Millioud, 1969. [69] [2].

C. oceanica Cookson and Eisenack, 1958. [31] [15].

Cribroperidinium edwardsi (Cookson and Eisenack, 1958) Davey, 1969a. [11] [3].

C. intricatum Davey, 1969a. [109] -

C. sepimentum Neale and Sarjeant, 1962. [56] [50].

Ctenidodinium elegantulum Millioud, 1969. (Plate 3, Figures 15, 16). [25].

Cyclonephelium distinctum Deflandre and Cookson, 1955, subsp. brevispinatum (Millioud, 1969) Lentin and Williams, 1973. [50] [62]. 
C. distinctum Deflandre and Cookson, 1955, subsp. longispinatum Davey, in press b. [105].-.

C. eisenacki Davey, 1969a. - [90].

C. hystrix (Eisenack, 1958) Davey, in press b [32] [4].

C. tabulatum Davey and Verdier, 1974. [17] [23].

C. cf. tabulatum Davey and Verdier, 1974. - [74].

Dingodinium albertii Sarjeant, 1966c. [26] [39].

Dinopterygium cladoides Deflandre, 1935. [89] -.

Discorsia nanna (Davey, 1974) Duxbury, 1977. - [28].

Ellipsodinium rugulosum Clarke and Verdier, 1967. [110] -.

Exochosphaeridium phragmites Davey et al., 1966. [2] [35].

Eyrea nebulosa Cookson and Eisenack, 1971. (Plate 5, Figure 13). [39] [75].

Florentinia deanei (Davey and Williams, 1966b) Davey and Verdier, 1973. [76] - .

F. mantellii (Davey and Williams, 1966b) Davey and Verdier, 1973. [36] [32].

$F$. radiculata (Davey and Williams, 1966b) Davey and Verdier, 1973. [80] [88].

Fromea amphora Cookson and Eisenack, 1958. [54] [5].

Gonyaulacysta cassidata (Eisenack and Cookson, 1960) Sarjeant, 1966b. [90] [56].

G. exilicristata Davey, 1969a. [103] -

G. fetchamensis Sarjeant, 1966b. [112]-

G. helicoidea (Eisenack and Cookson, 1960) Sarjeant, 1966b. [3] [61].

${ }^{*} G$. cf. helicoidea (Eisenack and Cookson, 1960) Sarjeant, 1966b. (Plate 3, Figures 11, 12). - [26].

G. cf. perforans (Cookson and Eisenack, 1958) Sargeant, 1969. - [40].

'G. polythris sp. nov. (Plate 3, Figures 1-3). [111]-.

G. tenuiceras (Eisenack, 1958) Sarjeant, 1969. [14] [53]

Gonyaulacysta sp. of Davey and Verdier, 1974. - [57].

*Hapsocysta dictyota sp. nov. (Plate 3, Figures 5-10, 13, 14). [91] -.

${ }^{*} H$. peridictya (Eisenack and Cookson, 1960) comb. nov. (Plate 4, Figures 1-5). [66] [72].

Heslertonia heslertonensis (Neale and Sarjeant, 1962) Sarjeant, 1966b. [29].

Hexagonifera chlamydata Cookson and Eisenack, 1962b. [92]-.

H. defloccata Davey and Verdier, 1973. [106] -.

"Histiocysta sp. A. (Plate 4, Figures 13, 14). [40] -.

Hystrichodinium dasys Davey, 1969a. (Plate 4, Figure 7). - [41].

H. pulchrum Deflandre, 1935. [4] [43].

Hystrichosphaeridium recurvatum (White, 1842) Davey and Williams, 1966b. [101] -.

H. cf. recurvatum (White, 1842) Davey and Williams, 1966b. - [48].

Kleithriasphaeridium loffrensis Davey and Verdier, 1976. [81] [86].

K. simplicispinum (Davey and Williams, 1966b) Davey, 1974. [37] [6].

Lecaniella foveata Singh, 1971. (Plate 4, Figure 6). [64] [69].

'Litosphaeridium arundum (Eisenack and Cookson, 1960) comb. nov (Plate 4, Figures 16, 17). [84] - .

L. conispinum Davey and Verdier, 1973. (Plate 4, Figure 15). [93] - .

L. siphoniphorum (Cookson and Eisenack, 1958) Davey and Williams, 1966b. [113] - .

?Maduradinium sp. A of Davey, in press b. [78] [87].

Meiourogonyaulax psoras Davey and Verdier, 1974. [27] - .

M. stoveri Millioud, 1969. [23] [21].

*Membranosphaera sp. A. (Plate 4, Figures 8-12). [24] [55].

Microdinium? crinitum Davey, 1969a. [67] [83].

Muderongia cf. staurota Sarjeant, 1966c. (Plate 5, Figures 4, 5). [51] [17].

*Nematosphaeropsis singularis sp. nov. (Plate 5, Figures 6, 10, 14). [52] [58].

*Nexosispinium hesperum sp. nov. (Plate 6, Figures 1-5). [28] [68].

*N. vetusculum (Davey, 1974) comb. nov.

Odontochitina operculata (O. Wetzel, 1933a) Deflandre and Cookson, 1955. [5] [9].

Oligosphaeridium complex (White, 1842) Davey and Williams, 1966b. [33] [10].

O. prolixispinosum Davey and Williams, 1966b. [86] - .

O. pulcherrimum (Deflandre and Cookson, 1955) Davey and Williams, 1966b. [60] -

*O. verrucosum sp. nov. (Plate 5, Figures 1-3). [57] [64].

*Ovoidinium diversum sp. nov. (Plate 6, Figures 6-16). [44] [59].

${ }^{*} O$. implanum sp. nov. (Plate 5, Figures 7-9, 11, 12). [107] -

*O. scabrosum (Cookson and Hughes, 1964) Davey, 1970. [82] -

*Ovoidinium sp. A. (Plate 6, Figures 17-20). [41] - .
Palaeohystrichophora cf. infusorioides Deflandre, 1935, of Davey and Verdier, 1973. [94] - .

Palaeoperidinium cretaceum Pocock, 1962, ex Davey, 1970. [43] [49].

Pareodinia ceratophora Deflandre, 1947c. [34] [54].

Polysphaeridium laminaspinosum Davey and Williams, 1966b. (Plate 7, Figure 10). [35] [22].

P. multispinosum Davey, 1974. - [76].

*P. pumilum Davey and Williams, 1966b. (Plate 7, Figures 2, 3). [83] - .

Polystephanephorus anthophorum (Cookson and Eisenack, 1958) Davey, in press a (Plate 7, Figures 1, 4, 9). [19] [65].

Prolixosphaeridium parvispinum (Deflandre, 1937b) Davey et al., 1969. (Plate 7, Figures 5-7). [20] [27].

Protoellipsodinium spinocristatum Davey and Verdier, 1971. [12] - .

P. spinosum Davey and Verdier, 1971. - [33].

Pseudoceratium pelliferum Gocht, 1957. - [67].

Pterodinium aliferum Eisenack, 1958. (Plate 7, Figures 13, 14). [6] [36].

$P$. cf. aliferum Eisenack, 1958. (Plate 7, Figure 12). [77] - .

Pterospermella aureolata (Cookson and Eisenack, 1958) Eisenack, 1972. [70] [51].

Schizocystia laevigata Cookson and Eisenack, 1962. - [89].

Scrinodinium campanula Gocht, 1959. [75] - .

Spinidinium gallium (Davey and Verdier, 1973) Lentin and Williams, 1976. [114] - .

Spiniferites cingulatus subsp. cingulatus (O. Wetzel, 1933b) Sarjeant, 1970. [7] [16].

"S. confossus sp. nov. (Plate 8, Figures 1-4). [61] - .

$S$. ramosus (Ehrenberg, 1838) subsp. multibrevis (Davey and Williams, 1966a) Lentin and Williams, 1973. [18] [11].

S. ramosus subsp. ramosus (Ehrenberg, 1838) Sarjeant, 1970. [8] [12].

$S$. ramosus (Ehrenberg, 1838) subsp. reticulatus (Davey and Williams, 1966a) Lentin and Williams, 1973. (Plate 7, Figures 8, 11). [9] [60].

Stephodinium coronatum Deflandre, 1936a. [95] - .

Subtilisphaera perlucida (Alberti, 1959b) Jain and Millepied, 1973. (Plate 8 , Figure 12). [45] [18].

S. terrula (Davey, 1974) Lentin and Williams, 1976. (Plate 8, Figure 11). [16] [71].

Surculosphaeridium longifurcatum (Firtion, 1952) Davey et al., 1966. [104].

S. trunculum sp. nov. (Plate 8, Figures 6-9). [53] [13].

"Systematophora cretacea sp. nov. (Plate 8, Figures 10, 13-15). [74] - .

Tanyosphaeridium boletum Davey, 1974. [29] [77].

$T$. cf. regulare Davey and Williams, 1966b. [62] [44].

T. variecalamum Davey and Williams, 1966b. [72] - .

Thalassiphora munda Davey and Verdier, 1973. [96] -

Trichodinium castanea (Deflandre, 1935) Clarke and Verdier, 1967. [10] [14].

Trichodinium sp. Davey and Verdier, 1974. (Plate 8, Figure 5). [58] [19].

Wallodinium luna (Cookson and Eisenack, 1960a) Lentin and Williams, 1973 [21] [38].

Xiphophoridium alatum (Cookson and Eisenack, 1962b) Sarjeant, 1966b [97] - .

\section{TAXONOMY}

Class DINOPHYCEAE Fritsch, 1929

Order PERIDINIALES Haeckel, 1894

\section{Genus ACHOMOSPHAERA Evitt, 1963}

\section{Achomosphaera cf. ramulifera (Deflandre) Evitt, 1963}

(Plate 1, Figure 1)

Remarks: Specimens attributed to $A$. cf. ramulifera differ from $A$. ramulifera s.s. by having mainly membranous processes. These are particularly well developed and noticeable in the cingular and dorsal postcingular regions. In contrast $A$. ramulifera has thin, usually hollow processes that are circular in cross-section.

\section{Achomosphaera sp. A \\ (Plate 1, Figures 4-6)}

Description: This is a subspherical to ovoid species composed of a thin, micropunctate to microgranulate wall from which arise a moderate number, approximately 30 , of slightly fibrous processes. Occasionally the processes are linked by surface ridges and more rarely by membranous 
crests. Although these ridges are probably sutural, a precise tabulation is not determinable. However, the processes do appear to be gonal in position and are of the Spiniferites ramosus-type. Distally, each process divides giving rise to two to several, sometimes irregular, spines. A small archeopyle is usually present and in both position and shape appears to be formed by the loss of a single precingular paraplate.

\section{Dimensions:}

Central body diameter

Length of processes

Range

24 (30) $36 \mu \mathrm{m}$

7 (10) $13 \mu \mathrm{m}$

Remarks: Achomosphaera sp. A is similar to $A$. cf. neptuni (Eisenack) of Davey and Verdier (1974) but has fewer and stouter processes. $A$. neptuni, from the Aptian of Germany, has fewer and considerably stouter processes than Achomosphaera sp. A.

\section{Genus BACCHIDINIUM gen. nov.}

Type species: Bacchidinium polypes (Cookson and Eisenack, 1962b) comb. nov. Albian-Cenomanian, Australia.

Derivation of name: This genus is named after the Roman god Bacchus

Diagnosis: The cysts are subspherical and bear many solid, mainly intratabular processes. One or more processes may be present per paraplate. Paratabulation is absent and the only polar structure that may be present is a small apical boss. Process alignment parallel to the paracingulum may be present. The archeopyle is dorsal precingular formed by the loss of one or two paraplates.

Remarks: Bacchidinium gen. nov. is a relatively simple genus and is characterized by its subspherical shape, solid, predominantly intratabular processes and its precingular archeopyle ${ }^{3}$. The superficially most similar genus is Operculodinium Wall, 1967, which has a type P archeopyle and solid intratabular processes. Stereoscan studies of $O$. centrocarpum (Deflandre and Cookson, 1955) Wall, 1967, by Harland (1973) and Jux (1976) show that the wall of this species is extremely fibrous and quite similar to that of Cordosphaeridium Eisenack, 1963b. Although the precise wal structure of $B$. polypes is unknown, this species is not considered to belong to the Exochosphaeridium-Cordosphaeridium lineage. Protoellipsodinium Davey and Verdier, 1971, is distinguished from Bacchidinium by being distinctly elongate in shape.

\section{Bacchidinium polypes polypes (Cookson and Eisenack, 1962b) comb. nov.} (Plate 1, Figure 7)

1962b Hystrichosphaeridium recurvatum var. polypes Cookson and Eisenack, p. 491, pl. 4, fig. 11.

1969a Cleistosphaeridium polypes (Cookson and Eisenack) Davey, p. 154

pl. 6 , fig. 7,8 .

Description: The wall of the cyst is smooth to lightly punctate and, being thin, is often deformed. The processes may be almost parallel-sided but often, as in the present material, they widen proximally. Distally the processes typically give rise to several small flexuous spines although in some specimens this type of termination is largely replaced by one that is recurved and non-spinose. Because both types of termination may occur on an individual specimen, specific differentiation is considered unnecessary. The distinctive type $2 \mathrm{P}$ archeopyle was observed in several specimens but in the majority of cases either the shape and position of the archeopyle could not be determined or no opening at all was apparent.

\section{Bacchidinium sarmentum sp. nov.} (Plate 1, Figures 8-12)

Derivation of name; Latin, sarmentum, twig-with reference to the distal branching of the processes.

Diagnosis: This is a thin-walled, subspherical species of Bacchidinium possessing one process per paraplate. The processes vary only slightly in size with the smallest ones occupying the sulcal region. The processes are relatively rigid and almost parallel-sided, although they do widen a little proximally where they may be striate. Distally they give rise to two to several stout spines orientated approximately parallel to the cyst wall. An archeopyle is typically present formed by the loss of a single precingular plate (3').

Holotype: MPK 1698, DSDP Leg 48, Hole 400A, Sample 69-1, 84-86 $\mathrm{cm}$. Aptian, northern Bay of Biscay.

\footnotetext{
${ }^{3}$ At the present it does not appear necessary to distinguish generically forms having one process per paraplate from those having several processes per paraplate; nor to place much significance on whether one or two precingular paraplates are lost in archeopyle formation.
}

\section{Dimensions:}

Central body diameter
Process length

$$
\begin{aligned}
& \text { Holotype } \\
& 33 \times 34 \mu \mathrm{m} \\
& 10-16 \mu \mathrm{m}
\end{aligned}
$$

Range $25(30) 34$

$15(16) 16 \mu \mathrm{m}$ (maxima)

Description: The processes average approximately $1.5 \mu \mathrm{m}$ in width and, because they are solid, are rarely deformed. The majority of the processes are of rather similar size with the slightly larger ones occupying the pre-, post-cingular, and antapical regions. These processes typically bear six to eight distal spines and these occasionally bifurcate medially; their overall span distally may be up to $15 \mu \mathrm{m}$.

Remarks: $B$. sarmentum sp. nov. differs from $B$. polypes by having fewer and stouter processes. Cleistosphaeridium tribuliferum (Sarjeant, 1962a) Davey et al. 1969 differs by possessing many more processes which only give rise to two to four spines distally.

\section{Genus CANNINGIA Cookson and Eisenack, 1960b}

Remarks: This genus is reserved for forms having in common an apical archeopyle (type A), low ornamentation, and lack a clear paratabulation.

\section{Canningia sp. A}

(Plate 3, Figure 4)

Description: This is a large, thin-walled species possessing a low density covering of granules and tubercules.

\section{Canningia sp. B}

(Plate 1, Figures 14, 15)

Description: This form has a rounded, subconical hypotract and is covered by a dense ornament of granules and low, variously shaped spines of up to $1.5 \mu \mathrm{m}$ in length.

Genus CANNOSPHAEROPSIS O. Wetzel, 1933b emend. Williams and Downie, $1966 \mathrm{c}$

\section{Cannosphaeropsis tutulosa Cookson and Eisenack, 1960a} (Plate 2, Figures 5-7)

1960a Cannosphaeropsis tutulosa Cookson and Eisenack, p.8, pl.2, fig. $12,13$.

Remarks: This species is subspherical in shape and has a small apical boss. Beneath this is the precingular archeopyle (3'). The parasutural processes do not appear to be arranged regularly along the paraplate boundaries and a Spiniferites-type of organization is not obvious. This is due to the complexity of the processes and to the dorso-ventrally flattened nature of the cysts which means that the processes and trabeculae are splayed out laterally.

Only a single example of $C$. tutulosa has been recovered from onshore sediments and that occurred near the base of the Gault Clay (middle Albian, $H$. dentatus Zone) in the Isle of Wight, southern England.

\section{Genus CODONIELLA Cookson and Eisenack, 1961a emend.}

Type species: Codoniella companulata (Cookson and Eisenack, 1960a, as Codonia), p. 11, pl. 3, fig. 1-3. Cenomanian-?Santonian, Australia.

Emended diagnosis: The cyst is subspherical and has either an incomplete or a complete paratabulation of the type $3-4^{\prime}, 6^{\prime \prime}, 6 \mathrm{c}, 5^{\prime \prime \prime}$ - 0-1p, $1^{\prime \prime \prime}$. The tabulation is marked by parasutural thickenings and sometimes crests in the paracingular, pre-, and postcingular regions, although it may be almost lacking here and confined to the apical and antapical regions. Along the parasutural boundaries between the apical and precingular and the antapical and postcingular paraplates there are developed regular and extremely high crests. The parasutural thickenings extend along these crests and distally continue, just inside the outer limit of the crests. Thus high membranous apical and antapical structures are formed which are open distally and supported by parasutural thickenings. Processes and a periphragm apical horn are absent. Pre- and postcingular crests may be present. The archeopyle is precingular ( $\left.3^{\prime \prime}\right)$.

Remarks: The diagnosis of Codoniella is here emended to particularly draw attention to the orientation of the cyst. The membranous extensions are now considered to be apical and antapical rather than equatorial and in this respect somewhat resemble those of Hystrichosphaeropsis (Deflandre, 1935) Sarjeant, 1966b, and Rottnestia Cookson and Eisenack, 1961b. Both of these genera, however, have an apical pericoel, with apical horn, and parasutural spines. The parasutural thickenings which occur distally jus within the outer margins of the crests are distinctive and, as yet, have only been recorded in one other genus, the genus Heslertonia Sarjeant, 1966b. 
The crests in this genus are evenly distributed and an epitractal archeopyle is present thus easily differentiating it from Codoniella.

Codoniella campanulata (Cookson and Eisenack) Downie and Sarjeant, 1965, emend.

(Plate 2, Figure 8)

1960a Codonia campanulata Cookson and Eisenack, p. 11, pl. 3, fig. 1-3.

1964 (1965) Codoniella companulata (Cookson and Eisenack) Downie and Sarjeant, p. 103.

Emended diagnosis: A thin-walled species of Codoniella which lacks paracingular tabulation and parasutural thickenings between the pre- and post-cingular paraplates. The crests surrounding the apical and antapical regions are very high and each forms a funnel-like structure which widens distally; these are strengthened by longitudinal thickenings and distal thickenings which occur just within the crest margin. Occasionally, crests extend from these structures along the pre- and postcingular paraplate boundaries to the paracingulum but these do not possess distal thickenings. The crests are almost smooth distally. An archeopyle is typically developed.

Holotype: Codoniella companulata (Cookson and Eisenack, 1960a, as Codonia), p. 11, pl. 3, fig. 1. Turonian, Western Australia.

Dimensions:

$\begin{array}{lcc} & \text { Holotype } & \text { Hole } 400 \mathrm{~A} \\ \text { Overall length } & 128 \mu \mathrm{m} & 88-96 \mu \mathrm{m} \\ \text { Endocyst diameter } & \text { c. } 46 \mu \mathrm{m} & 36-40 \mu \mathrm{m}\end{array}$

Remarks: $C$. campanulata is characterized by its high funnel-shaped, membranous structures extending apically and antapically from a thin walled, basically non-tabulate endocyst. Cookson and Eisenack (1960a) recorded it from the Cenomanian to ?Santonian of Western Australia: during the present study it was found only in Sections $62-2$ and $62-4$ in Hole $400 \mathrm{~A}$ of late Albian age.

\section{Codoniella psygma sp. nov. \\ (Plate 2, Figures 9-14)}

Derivation of name: Greek, psygma, fan - with reference to the shape of the polar structures.

Diagnosis: This is a species of Codoniella possessing a paracingulum which is clearly defined by parasutural thickenings. The boundaries between the pre- and postcingular paraplates are either defined by low parasutural thickenings or by crests, and in the latter case the thickening extends along the crest just within its outer border. An archeopyle is typically present.

Holotype: MPK 1680, DSDP Leg 48, Hole 400A, Sample 64-3, 52-55 $\mathrm{cm}$. Albian, northern Bay of Biscay.

\section{Dimensions:}

Overall length

Endocyst diameter

$\begin{array}{cc}\text { Holotype } & \text { Range } \\ 89 \mu \mathrm{m} & 59-89 \mu \mathrm{m} \\ 36 \times 40 \mu \mathrm{m} & 28-41 \mu \mathrm{m}\end{array}$

Description: The polar, funnel-like structures, typical of Codoniella, are well developed and the crests between the pre- and postcingular paraplates abut against them. The antapical funnel is simply composed of crests bordering the pre- and postcingular paraplates. However the apical funnel appears more complex in that, although the main funnel-shaped structure resembles that at the antapex, additional crests may be developed along apical paraplate boundaries. Distally the crests are smooth to slightly serrate.

Remarks: $C$. psygma sp. nov, may be distinguished from $C$. campanulata by its clearly defined paracingular tabulation. This species appears to have been illustrated by Habib (1972, pl. 15, fig. 3) as $\mathrm{Hy}$ strichosphaeropsis ovum from Leg 11, DSDP Hole 101A, Sample 6-1, $70-73 \mathrm{~cm}$, western North Atlantic; it is here probably of Apto-Albian age.

Genus GONYAULACYSTA Deflandre, 1964, ex Norris and Sarjeant, 1965

\section{Gonyaulacysta cf. helicoidea (Eisenack and Cookson, 1960)} Sarjeant, $1966 \mathrm{~b}$

(Plate 3, Figures 11, 12)

Description: This form is identical to $G$. helicoidea except that intratabular tubercules are absent.

Dimensions:

Overall length

Overall width
MPK 1757

$58 \mu \mathrm{m}$

$42 \mu \mathrm{m}$
Gonyaulacysta polythyris sp. nov.

(Plate 3, Figures 1-3)

Derivation of name: Greek, polys, many and thyris, window - with reference to the perforate crests.

Diagnosis: An ovoid species of Gonyaulacysta having a subconical apical horn and strongly developed, perforate parasutural crests. The crests are smooth distally, and are perforated by many variously sized holes. The cyst wall is thin, smooth, and bears a moderate number of stout intratabular spines. A precingular archeopyle is typically developed.

Holotype: MPK 1661, DSDP Leg 48, Hole 400A, Sample 62-2, 41-43 $\mathrm{cm}$. Albian, northern Bay of Biscay.

Dimensions:

Endocyst length

Endocyst width

Height of crests

$\begin{array}{cc}\text { Holotype } & \text { Range } \\ 54 \mu \mathrm{m} & 54-56 \mu \mathrm{m} \\ 42 \mu \mathrm{m} & 42-44 \mu \mathrm{m}\end{array}$

up to $9 \mu \mathrm{m} \quad 6-9 \mu \mathrm{m}$ (maxima)

Description: The crestal perforations are often elongate, with the long axis perpendicular to the cyst wall and, when several are present close together, the crest has a barred appearance. The crests are highest in the gonal regions and particularly at the margins of the apical and antapical plates. The intratabular spines are strongly developed (up to $3 \mu \mathrm{m}$ in height), solid, and tend to be rounded and not pointed distally.

Remarks: The combination of perforate crests and stout intratabular spines differentiates $G$. polythyris sp. nov. from all previously described species. The overall appearance of this species, however, indicates that it belongs to the $G$, helicoidea lineage.

\section{Genus HAPSOCYSTA gen. nov.}

Type species: Hapsocysta peridictya (Eisenack and Cookson, 1960) comb. nov. Aptian to Cenomanian, Australia.

Derivation of name: Greek, hapsis, mesh or network - with reference to the net-like structure surrounding the inner body.

Diagnosis: The cyst consists of a subspherical endocyst which is almost completely enveloped by a net-like periphragm structure: the areas between the strands may be filled by a subsidiary network. The net is joined to the endocyst only around the circumference of the archeopyle which is dorsal precingular $\left(3^{\prime \prime}\right)$ and this is the only part of the cyst not enclosed by the net. The mesh of the net is composed of a single strand or two closely adhering strands which are parasutural in position and define a tabulation. This consists of large, basically pentagonal, pre-, postcingular, and antapical areas, elongate paracingular areas and small, subcircular parasulcal areas; apical areas do not appear to be defined.

Remarks: The presence of a net-like structure almost completely surrounding the endocyst differentiates Hapsocysta gen. nov. from all previously described genera except Hapsidaulax Sarjeant, 1975, from the Bathonian of Scotland. Although the type species, H. margarethae Sarjeant, 1975, typically has parasutural crests, rare specimens were recorded in which these are lost leaving an open net-like structure superficially closely resembling that in $H$. peridictya. However the bipartite form of the meshes in $H$. peridictya is not present and tabulations differ considerably in that Hapsidaulax has an apical and anterior intercalary series of plates but not cingular series. Thalassiphora delicatn Williams and Downie, 1966c, differs by having a large dorsal opening in the periphragm membrane which is not otherwise perforate.

Hapsocysta appears to be closely related to Cannosphaeropsis which occurs at the same stratigraphic level in the present boreholes.

Hapsocysta peridictya (Eisenack and Cookson, 1960) comb. nov. and emend.

(Plate 4, Figures 1-5)

1958 Cannosphaeropsis fenestrata Deflandre and Cookson, p. 46, pl. 7, fig. 1-3.

1960 C. peridictya Eisenack and Cookson, p. 8, pl. 3, fig. 5, 6.

Emended diagnosis: A species of Hapsocysta having a relatively small, thin-walled endocyst which is almost completely surrounded by a large subspherical, wide-meshed, net-like structure. The bipartite strands of the net are smooth to lightly granular and generally closely adhere to each other. Where branching, the two strands tend to diverge and a very fine membrane is seen to connect them. An archeopyle is probably normally developed but is difficult to observe.

Holotype: Cannosphaeropsis peridictya Eisenack and Cookson, 1960, p. 8 , pl. 3 , fig. 6 .

Description: The bipartite strands of the net are partly hollow in some specimens but this feature is usually difficult to discern. Rarely, fine ridges 
occur on the endocyst and these probably partly define a tabulation. The thin-walled endocyst is typically distorted which makes orientation by archeopyle position extremely difficult. However, the small meshes of the parasulcal region (Pl. 4, Fig. 2, 5) are usually obvious and may be related to the elongate paracingular meshes ( $\mathrm{Pl}, 4$, Fig, 4) thus aiding in orientation.

\section{Hapsocysta dictyota sp, nov.}

(Plate 3, Figures 5-10, 13, 14)

Derivation of name: Greek, diktyon, net - with reference to the appearance of the outer membrane.

Diagnosis: A species of Hapsocysta possessing a thin, subspherical endocyst partly surrounded by an extensive net-like periphragm membrane. Parasutural ribs strengthen the latter structure and the thin periphragm of the intratabular regions is perforated by subpolygonal to circular holes of various sizes. The periphragm appears to join the endocyst around its lateral margins hence leaving most of the dorsal surface unenclosed. An archeopyle is typically present.

Holotype: MPK 1675, DSDP Leg 48, Hole 400A, Sample 63-2, 80-83 $\mathrm{cm}$, Albian, northern Bay of Biscay.

\section{Dimensions:}

Overall diameter

\section{Holotype}

$58 \times 64 \mu \mathrm{m}$

$32 \times 38 \mu \mathrm{m}$

Range

44 (60) $69 \mu \mathrm{m}$

26 (36) $52 \mu \mathrm{m}$

Description: Both the endocyst and the periphragm are extremely thin walled and easily distorted thus making the position of the archeopyle and the tabulation difficult to discern. However the large pre- and postcingular and elongate cingular paraplates are sometimes apparent. The intratabular perforations in the majority of specimens resemble those of the holotype in that they are typically quite large. However, rarer examples are present where the periphragm is perforated by only a few circular holes (Plate 3 , Figures $10,13,14)$. The parasutural ribs appear to consist of single hollow strands and are more strongly developed on the specimen having smaller perforations where gonal prominences are present around the antapical paraplate.

Remarks: $H$. dictyota sp. nov, is easily distinguished from $H$. peridictya by the presence of an intratabular periphragm membrane. The tabulation appears to be similar in both species, but in $H$. dictyota is defined by single strands and in $H$. peridictya by double strands. The only other species with a rather similar periphragm reticulation is Thalassiphora reticulata Morgenroth, 1966, from the Oligocene of Germany. The periphragm of this species differs, however, by its lack of tabulation, its antapical prolongation and that it almost completely surrounds the endocyst.

\section{Genus HISTIOCYSTA Davey, 1969a}

Histiocysta sp. A

(Plate 4, Figures 13, 14)

Description: The cyst is thick-walled (about $1 \mu \mathrm{m}$ ), subcircular in outline and superficially strongly resembles Membranosphaera sp. A which occurs at almost the same stratigraphic level. The tabulation is defined by thick, nodular ridges (up to $2 \mu \mathrm{m}$ in height) which, particularly in the paracingular region, are discontinuous. A coarse irregular network of intratabular ridges is present. An apical archeopyle with a strongly zigzag boundary is always present.

Dimensions:

Cyst length (operculum detached)

Cyst width

$\begin{array}{cc}\text { MPK } 1712 & \text { Range } \\ 42 \mu \mathrm{m} & 37-42 \mu \mathrm{m} \\ 32 \mu \mathrm{m} & 32.42 \mu \mathrm{m}\end{array}$

Genus LITOSPHAERIDIUM Davey and Williams, 1966b, emend. Davey and Verdier, 1973

Litosphaeridium arundum (Eisenack and Cookson, 1960) comb. nov. (Plate 4, Figures 16, 17)

1960 Hystrichosphaeridium arundum Eisenack and Cookson, p. 8, pl. 3, fig. 7-9.

Remarks: Litosphaeridium arundum comb. nov. closely resembles $L$. conispinum Davey and Verdier, 1973, in most respects including the number of processes, except that the paracingular and parasulcal processes of the former are tubular. In both species the paracingular and parasulcal processes are narrower than the other processes. The operculum usually remains attached in $L$. arundum and on one specimen was observed to bear three processes as does the operculum of $L$. siphoniphorum (Cookson and Eisenack, 1958).

Genus MEMBRANOSPHAERA Samoilovitch ex Norris and Sarjeant, 1965, emend. Drugg, 1967

Membranosphaera sp. A.

(Plate 4, Figures 8-12)

Description: This is a relatively thick walled (about $1 \mu \mathrm{m}$ ) cyst of subcircular outline. The cyst surface bears numerous short (about $2 \mu \mathrm{m}$ ) spines which vary in width, up to about $1 \mu \mathrm{m}$, and broaden distally where they sometimes bifurcate and link with adjoining ones. This linkage is most pronounced towards the lateral margins of the cyst where crest-like structures may develop; they are usually aligned longitudinally. These crests often give the impression that an outer membrane is present, but this is considered unlikely. Towards the centers of the dorsal and ventral surfaces the processes become reduced to tubercles. The apical archeopyle has a strongly zigzag margin and a deep parasulcal notch; the operculum is usually detached.

Dimensions:

\begin{tabular}{|c|c|c|c|}
\hline Dimensions: & MPK 1703 & MPK 1705 & Range \\
\hline $\begin{array}{l}\text { Cyst length } \\
\text { (operculum detached) }\end{array}$ & $34 \mu \mathrm{m}$ & & 32 (36) $44 \mu$ \\
\hline Cyst width & $36 \mu \mathrm{m}$ & & $32(38) 43 \mu$ \\
\hline Cyst length & & $41 \mu \mathrm{m}$ & \\
\hline
\end{tabular}

(complete specimen)

Remarks: Membranosphaera sp. A is abundant in Section 71-1 (Hole 400A) and rare in Sections 74-1 (Hole 400A) and 33-6 (Hole 402A). The present forms could not be adequately compared with the type material from western Siberia of Membranosphaera so no attempt was made to formulate a new species. Palaeostomocystis scrobiculata (Deflandre and Cookson, 1955) Cookson and Eisenack, 1974, is similar but appear to be less spiny, more elongate and is considerably larger.

Genus NEMATOSPHAEROPSIS Deflandre and Cookson, 1955, emend. Williams and Downie, 1966c

Nematosphaeropsis singularis sp. nov. (Plate 5, Figures 6, 10, 14)

Derivation of name: Latin, singularis, different - with reference to the unusual processes.

Diagnosis: The cyst is subspherical and is composed of a thin, lightly granular wall which bears variably shaped processes arising from low parasutural ridges. Both gonal and parasutural processes are present and vary from being broadly membranous to being quite delicate; branching may occur. All are of about equal height on an individual. Distally, each process expands before bifurcating or trifurcating to give rise to weak, generally smooth trabeculae which link adjacent processes along parasutural ridges. Although the latter are usually present, it is not possible to define the complete tabulation. An archeopyle is normally developed and appears to be precingular ( $\left.3^{\prime \prime}\right)$.

Holotype: MPK 1739, DSDP Leg 48, Hole 402A, Sample 25-5, 5-8 $\mathrm{cm}$. Aptian, northern Bay of Biscay.

Dimensions:

Central body diameter

Height of processes
Holotype

$42 \times 50 \mu \mathrm{m}$

6-12 $\mu \mathrm{m}$
Range 30 (38) $50 \mu \mathrm{m}$

7 (10) $15 \mu \mathrm{m}$ (maxima)
Description: Most of the processes are of the relatively simple, parallel-sided type which widen distally and are reminiscent of those occurring in the genera Spiniferites and Achomosphaera. However some processes are irregular and have both proximal and distal branching. The trabeculae are variably developed but this could partly be because of breakage.

Remarks: The variable form of the processes and the rather weak trabeculae distinguish $N$. singularis sp. nov. from other species in this genus. $N$. singularis has tentatively been assigned to Nematosphaeropsis because of its overall morphology. A clear Gonyaulacean tabulation has not been deciphered and the exact form of the archeopyle still remains in doubt. $N$. singularis has a last stratigraphic occurrence in the uppermost Aptian (?basal Albian) in Hole 400A.

\section{Genus NEXOSISPINUM gen. nov.}

Type species: Nexosispinum hesperum sp. nov., Aptian-?Albian, northern Bay of Biscay.

Derivation of name: Latin, nexosus, much intertwined or complicated - with reference to the anastomosing nature of the processes. 
Diagnosis: The cysts are spherical to subspherical and bear numerous, relatively short, solid processes which are apparently randomly arranged; they are of constant size upon an individual specimen. The processes are either simple or they anastomoze with one or more neighboring processes, sometimes forming an irregular network of linkages. Distally the processes are accuminate, capitate or briefly bifurcate. The archeopyle is precingular, formed by the loss of two plates (type 2P).

Remarks: The combination of short, randomly arranged, anastomozing processes and a type $2 \mathrm{P}$ archeopyle distinguishes Nexosispinum from previously described genera. Although occasionally some process alignment may be present, this cannot be related to a cyst tabulation. This lack of process organization and the type of process linkage easily distinguishes Nexosispinum from Cannosphaeropsis. Nexosispinum has a known stratigraphic range of Hauterivian to Aptian (?Albian).

\section{Nexosispinum hesperum sp. nov.} (Plate 6, Figures 1-5)

Derivation of name: Latin, hesperus, west - with reference to the westerly occurrence of this species relative to Europe.

Diagnosis: A species of Nexosispinum possessing a thin, lightly punctate or intraperforate wall. Simple processes are common; others anastomoze in an uncomplicated manner with one or two neighboring processes. The anastomozing is generally proximal or medial. The processes are either irregularly arranged over the cyst surface or they sometimes occur in small clumps or alignments. Distally, they are generally capitate or briefly bifurcate. An archeopyle is normally present.

Holotype: MPK 1723, DSDP Leg 48, Hole 402A, Sample 15-6, 23-26 $\mathrm{cm}$. Albian, northern Bay of Biscay.

\section{Dimensions:}

Endocyst diameter

Process length

\section{Holotype}

$40 \times 41 \mu \mathrm{m}$

6-7 $\mu \mathrm{m}$

Range

38 (47) $69 \mu \mathrm{m}$

6-9 $\mu \mathrm{m}$

Description: The thickness of the cyst wall and the processes are both about $0.5 \mu \mathrm{m}$. The exact shape of the archeopyle is normally very difficult to discern because of cyst distortion; occasionally the operculum remains in position

Remarks: $N$. hesperum sp. nov, differs from $N$. vetusculum comb. nov. by having a punctate wall and by the processes which are fewer in number, shorter, and less complexly linked. $N$. vetusculum has not been recorded above the early Barremian of England (Davey, 1974; Duxbury, 1977).

\section{OTHER SPECIES}

The following species, tentatively placed in Adnatosphaeridium by Davey, 1974, is here transferred to Nexosispinum.

Nexosispinum vetusculum (Davey) Davey, comb. nov. = Adnatosphaeridium vetusculum Davey, 1974, p. 45, pl. 1, fig. 1, 2. Early Barremian, England.

\section{Genus OLIGOSPHAERIDIUM Davey and Williams, 1966b}

Oligosphaeridium verrucosum sp. nov. (Plate 5, Figures 1-3)

Derivation of name: Latin, verruca, wart - with reference to the appearance of the cyst wall.

Diagnosis: A large subspherical species of Oligosphaeridium composed of a relatively thick periphragm which is discretely granular on the endocyst, but is smooth when it forms the processes. The latter are tubiform and distally terminate with a rather irregular secate-aculeate margin. The processes vary only slightly in size except the parasulcal and the posterior intercalary (1p) processes which are noticeably smaller. The endophragm is smooth beneath the processes. The apical archeopyle is usually de veloped and has a pronounced zig-zag margin and a deep parasulcal notch.

Holotype: MPK 1700, DSDP Leg 48, Hole 400A, Section 70-0. Aptian, northern Bay of Biscay.

Dimensions:

$\begin{array}{lcc}\text { Endocyst length } & \text { Holotype } & \text { Range } \\ \text { (archeopyle developed) } & 57 \mu \mathrm{m} & 50(53) 57 \mu \mathrm{m} \\ \text { Endocyst width } & 58 \mu \mathrm{m} & 50(57) 64 \mu \mathrm{m} \\ \text { Length of processes } & 34-48 \mu \mathrm{m} & 28-48 \mu \mathrm{m} \\ & 3-8 \mu \mathrm{m} & \text { (av. } \max .41 \mu \mathrm{m} \text { ) } \\ \text { Medial width of processes } & & 3-8 \mu \mathrm{m}\end{array}$

Description: The cyst wall varies from lightly to densely granular and, when the latter, the granules tend to be aligned on either side of the preand postcingular paraplate boundaries. Wall thickness varies up to $2 \mu \mathrm{m}$. The processes are strongly developed and sometimes appear to be fibrous. A smooth circular portion of endophragm is exposed beneath each process.

Remarks: This large, robust species of Oligosphaeridium occurs abundantly in Section 70-0 (Hole 400A), fairly commonly in Section 32-7, and rarely in Section 31-6, both of Hole 402A.

Genus OVOIDINIUM Davey, 1970, emend. Lentin and Williams, 1976

\section{Ovoidinium diversum sp. nov.} (Plate 6, Figures 6-16)

Derivation of name: Latin, diversus, different or diverse - with reference to the variable extension of the outer membrane.

Diagnosis: The cyst is subspherical in shape and composed of a very thick, intraperforate endophragm and a variably developed, thin periphragm. The latter may closely adhere to the endophragm or it may be quite distinct and sometimes forms irregularly shaped protuberances; in the latter case the pericoel is also irregularly developed. The combination archeopyle, of type $\overline{4 \mathrm{~A} 3 \mathrm{I}}$, is always developed and the operculum often remains attached; endophragm and periphragm always remain attached in the operculum.

Holotype: MPK 1740, DSDP Leg 48, Hole 402A, Sample 25-5, 5-8 $\mathrm{cm}$. Apto-Albian, northern Bay of Biscay.

Paratype 1: MPK 1720, DSDP Leg 48, Hole 402A, Sample 13-2, 93-96 cm. Apto-Albian, northern Bay of Biscay.

Paratype 2: MPK 1697, DSDP Leg 48, Hole 402A, Sample 68-2, 24-26 cm. Apto-Albian, northern Bay of Biscay.

\section{Dimensions:}

Length of endocyst

Length of endocyst

Width of endocyst
Height of periphragm (with operculum)

(without operculum)

Widthout operculn

$$
\begin{aligned}
& \text { Holotype } \\
& 68 \mu \mathrm{m}
\end{aligned}
$$$$
\begin{gathered}
\text { Paratype } 1 \\
50 \mu \mathrm{m}
\end{gathered}
$$

Paratype 2
$44 \mu \mathrm{m} \quad 38(45) 49 \mu \mathrm{m}$

$46 \mu \mathrm{m} \quad 38(51) 74 \mu \mathrm{m}$

$64 \mu \mathrm{m} \quad 52 \mu \mathrm{m} \quad 46 \mu \mathrm{m} \quad 38$ (51) $74 \mu \mathrm{m}$

Description: The endophragm is very thick, usually about $4 \mu \mathrm{m}$, and is strongly intraperforate which gives the wall a spongy appearance. Rarely, very poorly developed lines on the wall surface partly define a tabulation. Only occasionally does the periphragm adhere so closely to the endophragm that no pericoel is formed (see Paratype 2). The holotype represents an average specimen in the range of variation in that the thin, wrinkled, hyaline periphragm appears to form a loose enveloping cover around the endocyst. Paratype 2 is an extreme example where the periphragm is well developed but not irregularly, as is normally the case, but forms high extensions over the pre-, postcingular, and antapical paraplates areas. The archeopyle is that typical for the genus and includes the removal of four apical and three intercalary plates as a single unit (Evitt, 1967). The most distinctive characteristic of the archeopyle, which could be mistaken for a simple apical archeopyle (type $\overline{\mathrm{A}}$ ), is the straight paraplate boundary parallel to the paracingulum on the dorsal surface. This is the boundary between paraplate $2 a$, included within the operculum, and paraplate $4 "$.

Remarks: The thickness of the endophragm and particularly the irregular development of the periphragm distinguishes $O$. diversum $\mathrm{sp}$. nov. from all previously described species. In most other species of Ovoidinium the periphragm is relatively consistent in its development and regular apical and antapical pericoels are present. Hence the original concept of Ovoidinium has been modified and more emphasis is now placed on the presence of the unique $\overline{4 \mathrm{~A} 3 \mathrm{I}}$ archeopyle type. The most similar species to $O$. diversum is $O$. indistinctum (Cookson and Eisenack) Lentin and Williams, 1975, from the Apto- ?Albian of Western Australia, which, however, apparently does not have a thick, intraperforate endophragm. The Australian species is also considerably larger - overall length 86 to $104 \mu \mathrm{m}$, overall width 66 to $96 \mu \mathrm{m}$. All other members of this genus are also of mid-Cretaceous age.

$O$. diversum is rare in Hole 400A (Cores 71 to 64 ) but often abundant in Hole $402 \mathrm{~A}$ (Cores 32 to 11 ). This species has only been found in one onshore sample in the $H$. jacobi Zone (Upper Aptian) of the basal Sandrock-top Ferruginous Sands at Atherfield Bay, Isle of Wight.

\section{Ovoidinium implanum sp. nov.}

(Plate 5, Figures 7-9, 11, 12)

Derivation of name: Latin, implanus, uneven - with reference to the rough wall of the cyst. 
Diagnosis: A subspherical to ovoid species of Ovoidinium composed of endophragm and periphragm both of moderate thickness; the apical region is broadly subconical. The periphragm is closely adpressed to the endophragm except at the antapex where a small pericoel is usually present and at the apex where occasionally an apical pericoel exists. The periphragm is strongly ornamented and all gradations exist from coarse irregularly shaped pits (fossulate-foveolate ornamentation) to a dense, fine intraperforation. A pericingulum and antapically widening perisulcus are usually noticeable. The combination archeopyle (type $\overline{4 \mathrm{A3} 1}$ ) is always developed and the operculum often remains attached.

Holotype: MPK 1668, DSDP Leg 48, Hole 400A, Sample 62-4, $111-113 \mathrm{~cm}$. Albian, northern Bay of Biscay.

Dimensions:

Overall length (complete specimen)

Overall length (operculum detached)

Holotype $54 \mu \mathrm{m}$

Range 40 (49) $56 \mu \mathrm{m}$ c. $40 \mu \mathrm{m}$ Width

Height of antapical pericoel
40 (44) $48 \mu \mathrm{m}$ 0-5 $\mu \mathrm{m}$

Description: The wall layers are each of about $0.5 \mu \mathrm{m}$ in thickness. The endophragm appears to be smooth whereas the periphragm has a characteristically strong ornamentation and, although some positive elements may occasionally be detected around the lateral margins of the cyst, it appears most probably that a negative ornamentation is typical. The antapical periphragm extension when present, may either be almost symmetrical (see holotype) or may be more strongly developed on the left side.

Remarks: The reduced pericoels and the structure of the periphragm distinguishes $O$. implanum sp. nov. from all previously described species. This distinctive species only occurred in Section 62-4 where it was common.

\section{Ovoidinium scabrosum (Cookson and Hughes) Davey, 1970}

Remarks: The hypopericystal opening, characteristic of other species in this genus, is well developed on some specimens.

\section{Ovoidinium sp. A}

(Plate 6, Figures 17-20)

Description: The subspherical to ovoidal endocyst is relatively thick (about $1 \mu \mathrm{m}$ ) and is lightly granular. The thin membranous periphragm encloses an extensive hypotractal pericoel, largest at the antapex, which is of variable shape. The periphragm is more closely adpressed in the epitratal region and only reduced pericoels are sometimes present here The archeopyle has a pronounced zigzag margin with a deep parasulcal notch. The archeopyle appears to be of the combination type (4A31) but in many specimens this is impossible to verify and simply appears to be "apical."

\section{Dimensions:}

Endocyst length (complete specimen)

Endocyst length

(archeopyle development)

Endocyst width

$\begin{array}{cc}\text { MPK 1716 } & \begin{array}{c}\text { Range } \\ 42-50 \mu \mathrm{m}\end{array} \\ 39 \mu \mathrm{m} & 39-42 \mu \mathrm{m} \\ 37 \mu \mathrm{m} & 37-44 \mu \mathrm{m}\end{array}$

Remarks: Ovoidinium sp. A resembles Hexagonifera defloccata Davey and Verdier, 1973, which however does not have a strongly indented archeopyle margin. The reattribution of $H$. defloccata to Thalassiphora Eisenack and Gocht, 1960 by Lentin and Williams, 1975, is here rejected. Both $H$. defloccata and $H$. chlamydata Cookson and Eisenack, 1962b, appear to have apical archeopyles as is indicated by the detached operculum in Davey, 1970 (pl. 3, fig. 9). However, the author agrees that these species do not belong in the genus Hexagonifera Cookson and Eisenack, 1961a. Ovoidinium sp. A occurs only in Section 72-3, Hole $400 \mathrm{~A}$, where it is abundant.

\section{Genus POLYSPHAERIDIUM Davey and Williams, 1966b}

\section{Polysphaeridium pumilum Davey and Williams, 1966b} (Plate 7, Figures 2, 3)

Remarks: Specimens definitely attributable to $P$. pumilum occur in Core 62 (Hole 400A) but in lower samples, particularly in Core 64, specimens tend to increase in size and have fewer processes. Whereas the Cenomanian type-material was described as having a maximum endocyst diameter of $25 \mu \mathrm{m}$, the Core 64 specimens range up to $36 \mu \mathrm{m}$; process

length in the Cenomanian forms is 7 to $10 \mu \mathrm{m}$ and in Core 64 it is 10 to 15 $\mu \mathrm{m}$; process number in the Cenomanian is 38 to 44 and in Core 64 it is often under 30 . Finally the Core 64 specimens tend to have the thickish intraperforate wall which is rather similar to that found in Litosphaeridium. Numbers of specimens are insufficient at present to assess the significance of the above variation.

\section{Genus SPINIFERITES Mantell, 1850, emend. Sarjeant, 1970}

Remarks: There is some difficulty in distinguishing Spiniferites cingulatus $(\mathrm{O}$. Wetzel) from Pterodinium aliferum Eisenack and the genus Leptodinium; undoubtedly all are closely related and intermediate forms can occur. Leptodinium is reserved for specimens having low sutural crests which are smooth distally and are of constant height. S. cingulatus cingulatus also has smooth sutural crests but they are supported by gonal thickenings that distally may bifurcate briefly; the crests are highest in the gonal areas and become lower in between. $P$. aliferum generally has higher, more flexuous crests that are serrate distally.

\section{Spiniferites confossus sp. nov. (Plate 8, Figures 1-4)}

Derivation of name: Latin, confossus, full of holes-with reference to the perforate nature of the parasutural crests.

Diagnosis: A subspherical to ovoidal species of Spiniferites possessing a thin, smooth to lightly punctate wall and a clear tabulation defined by high perforate crests. The crests tend to be highest in the gonal areas and generally more strongly developed towards the antapex. The outer limit of the crests is always entire, usually smooth, and sometimes noticeably thickened. The perforations are smooth in outline, vary considerably in size and, when large, the crest may be represented only by a distal trabeculum. A precingular archeopyle is typically developed.

Holotype: MPK 1732, DSDP Leg 48, Hole 400A, Sample 69-1, 84-86 $\mathrm{cm}$. Aptian, northern Bay of Biscay.

Dimensions:

Endocyst length

Endocyst width

Height of crests
Range

36 (39) $42 \mu \mathrm{m}$

29 (32) $34 \mu \mathrm{m}$

9 (11) $14 \mu \mathrm{m}(\max$. the crests perpendicular to the cyst surface. Although the crests are generally smooth distally, sometimes a slight notching is weakly developed.

Remarks: This distinctive species is distinguished from other rather similar forms by the presence of high perforate sutural crests. It is considered most comparable to Spiniferites cingulatus (O. Wetzel) although its high crests are reminiscent of Pterodinium aliferum Eisenack which, however, possesses denticulate crests. S. confossus could possibly have been assigned to Nematosphaeropsis but the latter genus should probably be restricted to species having definite gonal processes.

\section{Genus SURCULOSPHAERIDIUM Davey et al., 1966}

\section{Surculosphaeridium trunculum sp. nov.} (Plate 8, Figures 6-9)

Derivation of name: Latin, trunculus, trunk-with reference to the trunk-like appearance of the proximal part of the processes.

Diagnosis: A smooth walled, subspherical species of Surculosphaeridium possessing one, or more rarely two, solid processes per paraplate. The wider processes, which occupy the pre-, postcingular, antapical regions, typically have a proximal bifurcation giving the processes a basal subconical perforation. Often, particularly in the paracingular region, the processes may be deeply furcate or a single paracingular process may be represented by two finer processes; sometimes these latter processes are joined by a medial bar. Distally the processes fork irregularly. An archeopyle is usually developed.

Holotype: MPK 1742, DSDP Leg 48, Hole 402A, Sample 25-5, 5-8 $\mathrm{cm}$. Apto-Albian, northern Bay of Biscay.

\section{Dimensions:}

Endocyst diameter Process length

Holotype
$32 \times 39 \mu \mathrm{m}$
$11-16 \mu \mathrm{m}$

Range $26(35) 44 \mu \mathrm{m}$ 10 (15) $20 \mu \mathrm{m}$

Description: The processes vary considerably in width with the widest processes occupying the pre-, postcingular, and antapical regions; parasulcal processes are the thinnest. The apical and paracingular processes 
are intermediate in size. As in other species of Surculosphaeridium the paracingular processes may be furcate, sometimes deeply so, and, when this furcation extends to the cyst wall, the paracingular plate then bears two processes. Distally the processes typically birfucate or trifurcate and terminate with a small birfucation or spinelets.

Remarks: Superficially $S$, trunculum sp. nov, is most similar to $S$. longifurcatum (Firtion, 1952) Davey et al., 1966, and is probably ancestral to it. S. trunculum has to date only been recorded from the Aptian and $S$. longifurcatum has a known first stratigraphic occurrence in the basal middle Albian (see Davey and Verdier, 1971). Neither species has so far been recorded from the lower Albian. $S$. trunculum differs from $S$. longifurcatum by the possession of two very distinctive process types. Firstly are the type that birfurcate proximally having a subconical basal perforation, and secondly are the thinner processes, usually paracingular, that are linked by a medial bar. Some of the processes of Systematophora complicata Neale and Sarjeant, 1962, have a similar medial linkage but are considerably more complex. $S$. complicata as illustrated by Duxbury (1977; pl. 7, fig. 8) may be identical to $S$. trunculum.

\section{Genus SYSTEMATOPHORA Klement, 1960}

Systematophora cretacea sp. nov.

(Plate 8, Figures 10, 13-15)

1971 Systematophora fasciculigera Klement, in Davey and Verdier, p. 35 , pl. 6 , fig. 10,11 .

1975 S. fasciculigera Klement, in Verdier, p. 194-196.

Derivation of name: Named after the Cretaceous System.

Diagnosis: A subspherical species of Systematophora composed of a thick, densely granular wall which bears processes arranged in annular complexes. Each complex gives rise to a number of processes which may subdivide distally. Proximally the annular complexes arise from circular to rounded-triangular thickenings of the cyst wall. They vary considerably in size with the larger ones occupying the pre-, postcingular, and antapical regions; the apical and parasulcal complexes are smaller and the paracingulum is marked by a small, elongate complex which bears two simple processes. The parasulcal region may have simple processes. An apical archeopyle always appears to be developed.

Holotype: MPK 1683, DSDP Leg 48, Hole 400A, Sample 64-3, 52-55 $\mathrm{cm}$. Albian, northern Bay of Biscay.

Dimensions:

Endocyst length Holotype $72 \mu \mathrm{m}$

(operculum attached)

Endocyst length

(operculum detached)

Endocyst width

Length of processes

$\begin{array}{cc} & 60-64 \mu \mathrm{m} \\ 69 \mu \mathrm{m} & 56-69 \mu \mathrm{m} \\ 12-20 \mu \mathrm{m} & 16(20) 24 \mu \mathrm{m} \\ & \text { (maxima) }\end{array}$

Description: The largest annular complexes occupy the pre-, postcingular, and antapical regions and here the larger ones are membranous proximally and only divide into spines medially. In the smaller complexes the processes tend to rise directly from the proximal thickening. The size of each annular complex is related directly to the size of the paraplate, and those occupying the pre- and postcingular regions tend to be of a rounded triangular shape.

Remarks: $S$. cretacea sp. nov. strongly resembles $S$. fasciculigera Klement, 1960, which differs by having longer and more complex processes and by not having a thick granular wall. $S$. valensii (Sarjeant, 1960) Downie and Sarjeant, 1964, is also similar and may, in fact, be synonymous with $S$. fasciculigera.

\section{ACKNOWLEDGMENTS}

I would like to thank Miss Linda Murgatroyd for preparing the samples and for constructing the range-distribution charts. Thanks are also due to Drs. G. Dörhöfer, R. Harland, and B. Owens for their constructive comments of the manuscript. The author publishes with the approval of the Director, Institute of Geological Sciences, London. The author would also like to acknowledge the interest shown by the Department of Energy in funding participation in the Deep Sea Drilling Project.

\section{REFERENCES}

(All references to dinocysts mentioned in the text but not listed below are to be found in Lentin and Williams, 1973, 1975.)
Brideaux, W. W. and McIntyre, D. J., 1975. Miospores and microplankton from Aptian-Albian rocks along Horton River, District of Mackenzie, Geological Survey of Canada Bulletin 252 , p. $1-85$.

Burger, D., in press. Palynological studies in the Great Artesian Basin, Australia. Part 1: Lower Cretaceous, Surat Basin, Queensland, Bureau of Mineral Resources, Australia.

Cookson, I. C. and Eisenack, A., 1974. Mikroplankton aus Australischen Mesozoischen und Tertiaren Sedimenten, Palaeontographica, v. 148, p. 44-93.

Davey, R. J., in press a. The stratigraphic distribution of dinocysts in the Portlandian (latest Jurassic) to Barremian (Early Cretaceous) of northwest Europe, American Association of Stratigraphic Palynologists, Contribution Series.

, in press b. Marine Cretaceous palynology of Site 361, DSDP 40, off southwestern Africa. In Bolli, H.M., Ryan, W.B.F., et al., Initial Reports of the Deep Sea Drilling Project, v. 40: Washington (U.S. Government Printing Office), p. 883-914.

Davey, R. J, and Verdier, J. P., 1976. A review of certain non-tabulate Cretaceous hystrichospherid dinocysts, Review of Palaeobotany and Palynology, v. 22, p. 307-335.

Duxbury, S., 1977. A palynostratigraphy of the Berriasian to Barremian of the Speeton Clay of Speeton, England, Palaeontographica, v. 160, p. 17-67.

Evitt, W. R., 1967. Dinoflagellate studies. II. The archeopyle, Stanford University Publications, Geological Sciences, v. 10, p. 1-83.

Fritsch, F. E., 1929. Evolutionary sequence and affinities among Protophyta, Biological Review, v. 4, p. 103-151.

Haeckel, E., 1894. Entwurf eines natürlichen Systems der Organismen auf Grund ihrer Stammegeschichte, Erster Theil. Systematische Phylogenic der Protisten und Pflanzen: Berlin (Georg Reimer).

Harada, K., 1974. Distribution of fossil microplankton in surface sediments on the continental margin of the Pacific off Japan. Masters thesis, University of Kyoto, Japan, p. 1-25.

Harland, R., 1977. Recent and late Quaternary (Flandrian and Devensian) dinoflagellate cysts from marine continental shelf sediments around the British Isles, Palaeontographica, v. 164, p. $87-126$.

Jux, U., 1976. Über den feinbau der Wandungen bei Operculodinium centrocarpum (Deflandre and Cookson) Wall, 1967, und Bitectatodinium tepikiense Wilson, 1973, Palaeontographica, v. 155, p. 149-156.

Lentin, J. K. and Williams, G. L., 1973. Fossil Dinoflagellates; index to genera and species, Geological Survey of Canada Paper, no. 73-42, p. 1-176.

-, 1975 . Fossil dinoflagellates: index to genera and species. Supplement 1, Canadian Journal of Botany, v. 53, p. $2147-2157$.

P. 1976. (1975). A monograph of fossil peridinoid dinoflagellate cysts, Bedford Institute of Oceanography, Report Series 75-16, p. 1-237.

Norvick, M. S. and Burger, D., 1976. Palynology of the Cenomanian of Bathurst Island, Northern Territory, Australia, Bureau of Mineral Resources, Australia, Bulletin 15I, p. $1-169$.

Ostenfeld, C. H., 1903. Phytoplankton from the sea around the Faeroes. In Botany of the Faeroes, Part 2 Det Nordiske Verlag, Copenhagen: London (J. Weldon and Co.), p. 558-612.

Reid, P. C., 1974. Gonyaulacean dinoflagellate cysts from the British Isles, Nova Hedwigia, v. 25, p. 579-637.

Reid, P. C. and Harland, R., in press. Studies of Quaternary dinoflagellate cysts from the North Atlantic, American Association of Stratigraphic Palynologists, Contribution Series. 
Sarjeant, W. A. S., 1975. Hapsidaulax, new genus of dinoflagellate cysts from the Jurassic (Bathonian) of the Isle of Syke, Scottish Journal of Geology, v. 11, p. 143-149.

Smith, A. G., Briden, J. C., and Drewry, G. E., 1973. Phanerozoic world maps. In Organisms and Continents through time: Special Papers in Palaeontology, no. 12, p. $1-42$.
Verdier: J.-P., 1975. Les kystes de dinoflagelles de la section de Wissant et leur distribution stratigraphique au Crétacé moyen, Revue de Micropaléontologie, v. 17, p. 191-197.

Williams, G. L. and Brideaux, W. W., 1975. Palynologic analyses of Upper Mesozoic and Cenozoic rocks of the Grand Banks, Atlantic continental margin, Geological Survey of Canada Bulletin 236, p. 1-163. 


\section{PLATE 1}

$($ Magnification $\times 500)$

Figure 1

Achomosphaera cf. ramulifera (Deflandre). MPK 1660. Sample 402A-62-2, 41-43 cm. Dorsal view.

Figures 2, 3 Achomosphaera cf. neptuni (Eisenack).

2. MPK 1711. Sample 400A-72-3, 40-42 cm.

3. MPK 1756. Sample 402A-34-3, 94-98 cm. Dorsal surface with precingular $\left(3^{\prime \prime}\right)$ archeopyle (arrow) and aligned paracingular processes (interference contrast).

Figures 4-6

Achomosphaera sp. A. Sample 400A-63-2, 80-83 $\mathrm{cm}$.

4, 5. MPK 1673. 4, dorsal surface with precingular $\left(3^{\prime \prime}\right)$ archeopyle (arrow). 5, ventral surface. (Interference contrast).

6. MPK 1674 (phase contrast).

Figure 7 Bacchidinium polypes subsp. polypes (Cookson and Eisenack) MPK 1738. Sample 402A-25-5, 5-8 cm. Dorsal surface with precingular (2P) archeopyle; arrow points to re-entrant angle of archeopyle (interference contrast).

Figures 8-12 Bacchidinium sarmentum sp. nov. 8, 9, 12, Sample 400A-69-1, 84-86 cm. 10, 11, Sample 400A-65-2, $19-22 \mathrm{~cm}$.

8. Holotype. Arrow indicates precingular archeopyle (interference contrast).

9. Holotype. Detail of process terminations (interference contrast).

10. MPK 1687. Arrow indicates precingular archeopyle (interference contrast).

11. MPK 1687. Arrow indicates precingular archeopyle.

12. Holotype. Arrow indicates precingular archeopyle.

Figure 13 Baltisphaeridium crameri Singh. MPK 1734. Sample 402A-23-6, 35-38 cm.

Figures 14, 15 Canningia sp. B.

14. MPK 1737. Sample 402A-24-5, 13-16 cm.

15. MPK 1735. Sample 402A-23-6, $87-91 \mathrm{~cm}$. (Phase contrast). 
PLATE 1
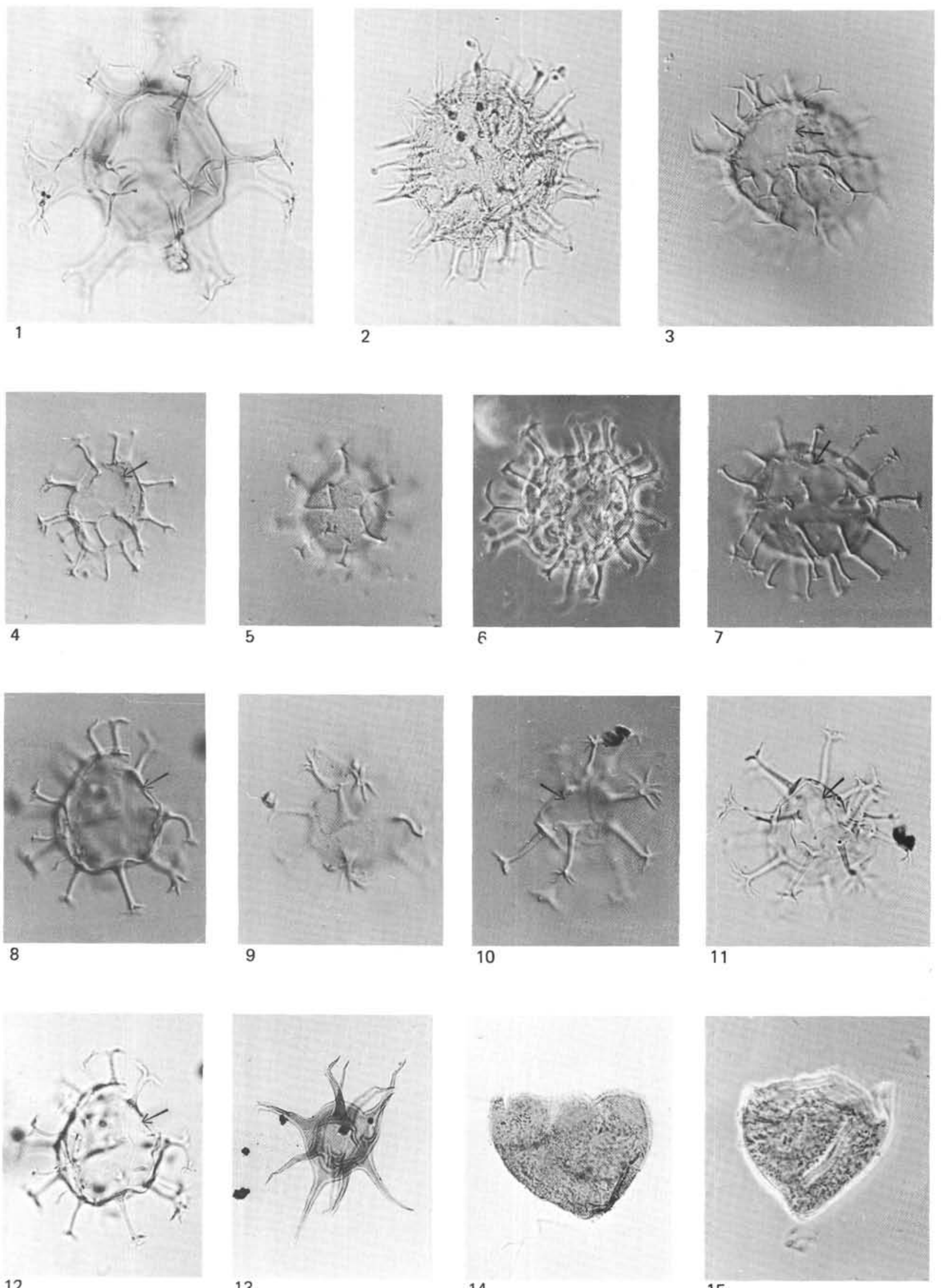

14

15 
PLATE 2

(Magnification $\times 500$ )

Figure 1 Callaiosphaeridium asymmetricum Deflandre and Courteville. MPK 1747. Sample 402A-30-6, 60-63 $\mathrm{cm}$. Antapical view; arrow indicates parasulcal processes.

Figure 2 Canningia colliveri Cookson and Eisenack. MPK 1694. Sample 400A-68-2, 24-26 cm.

Figure 3 Cassiculosphaeridia reticulata Davey. MPK 1702. Sample 400A-71-1, 111-113 cm. Ventral view illustrating parasulcal notch.

Figure 4 Canningia ringnesii Manum and Cookson. MPK 1965. Sample 400A-68-2, 24-26 cm. Operculum partly attached.

Figures 5-7 Cannosphaeropsis tutulosa Cookson and Eisenack. MPK 1665. Sample 400A-62-4, 111-113 cm.

5. Ventral view (interference contrast).

6. Ventral view (phase contrast).

7. Dorsal surface; arrow indicating precingular archeopyle (phase contrast).

Figure $8 \quad$ Codoniella campanulata (Cookson and Eisenack). MPK 1666. Sample 400A-62-4, 111-113 cm. Ventral surface; arrow indicates parasutural crest thickenings.

Figures 9-14 Codoniella psygma sp. nov.

9, 10. Holotype. 9, dorsal surface; arrow indicating precingular archeopyle immediately above the well defines paracingulum. 10, ventral view.

11, 12. MPK 1748. Sample 402A-30-6 60-63 cm. 11 , lateral view; arrow indicates precingular archeopyle. 12, lateral view.

13. MPK 1755. Sample 402A-32-7, 0-4 cm.

14. MPK 1696. Sample 400A-68-2, 24-26 cm. Parasutural thickenings very noticeable (interference contrast). 
PLATE 2

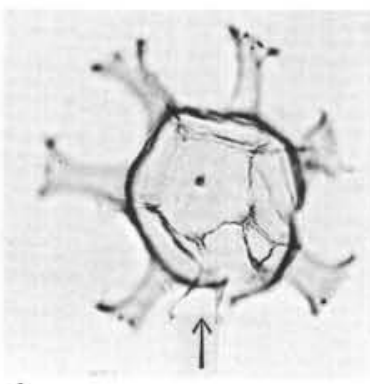

1

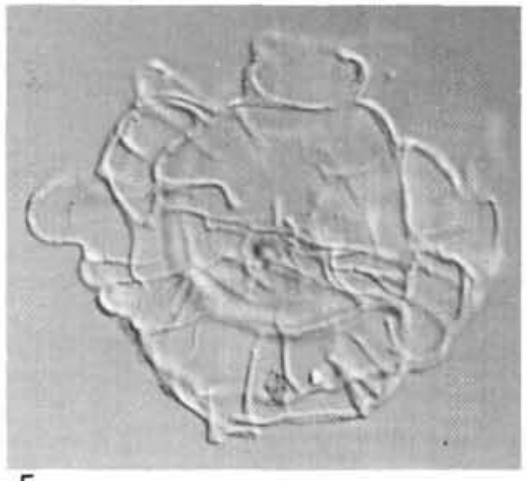

5

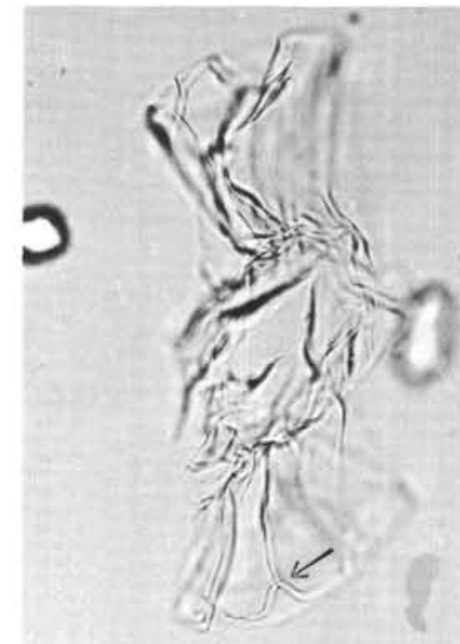

8

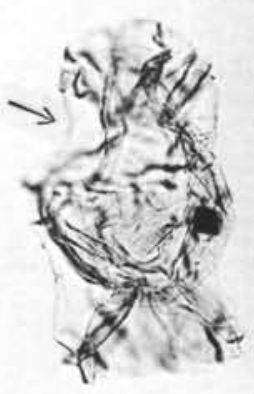

11

12

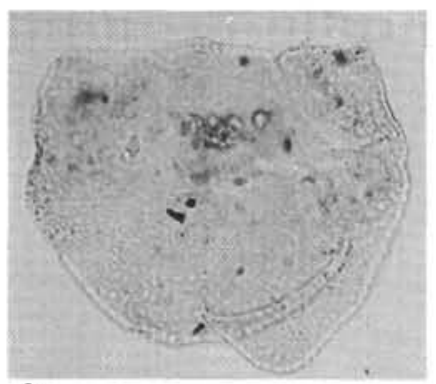

2

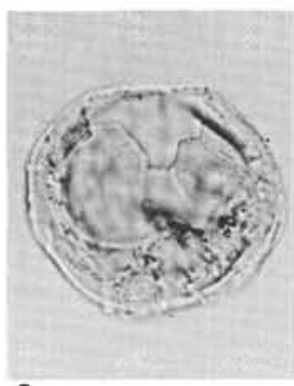

3

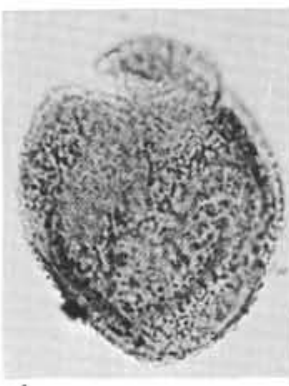

4
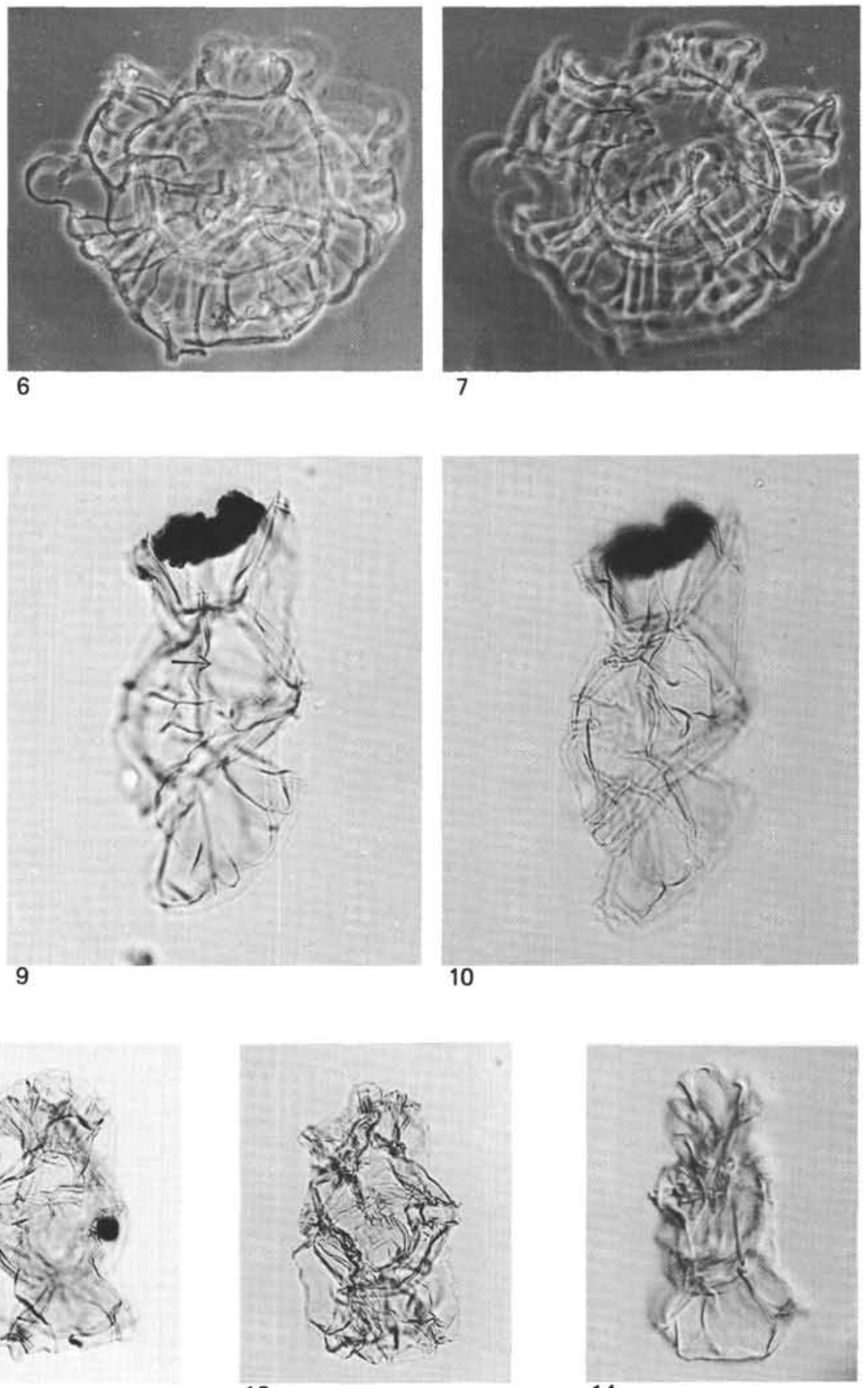

13

14 
PLATE 3

(Magnification $\times 500$ unless otherwise stated.)

Figures 1-3 Gonyaulacysta polythris sp. nov. Holotype. 3, note perforations in precingular crest. $\times 1250$ (phase contrast).

Figure 4 Canningia sp. A. MPK 1681. Sample 402A-64-3, $52-55 \mathrm{~cm}$ (phase contrast).

Figures 5-10, Hapsocysta dictyota sp. nov.

5, 6. Holotype. 5, ventral surface. 6, dorsal surface; arrow indicates precingular archeopyle (interference contrast).

7. MPK 1662. Sample 400A-62-2, 41-43 cm. Arrow indicates parasutural ribs (phase contrast).

8. MPK 1676. Sample 400A-63-2, 80-83 cm. Dorsal surface; arrow indicates precingular archeopyle. Note that most of the dorsal surface is not enclosed by the outer net.

9. MPK 1677. Sample 400A-63-2, 80-83 cm. Lateral view.

10. MPK 1678. Sample 400A-63-2, 80-83 cm. Antapical view. Note perforations are smaller and more circular than in the holotype (phase contrast).

13, 14. MPK 1679. Sample 400A-63-2, 80-83 cm. Lateral views. 13, arrow indicates position of archeopyle. Note small circular perforations in this extreme specimen. 14, note bifurcating parasutural ribs (phase contrast).

Figures 11, 12 Gonyaulacysta cf. helicoidea (Eisenack and Cookson). MPK 1757. Sample 402A-35-1, 108-111 cm. Note that the antapical plate is displaced completely onto the dorsal surface of the hypocyst.

11. Dorsal surface with developed archeopyle.

12. Ventral surface.

Figures 15, 16 Ctenidodinium elegantulum Millioud. MPK 1759. Sample 402A-35-3, 69-72 cm.

15. Ventral surface of epicyst.

16. Dorsal surface of epicyst. 
PLATE 3

PLATE 4

(Magnification $\times 500$ unless otherwise stated.)

Figures 1-5 Hapsocysta peridictya (Eisenack and Cookson).

1. MPK 1692. Sample 400A-67-0. Lateral view; arrow indicates the parasutural strand of a postcingular paraplate (interference contrast).

2. MPK 1729. Sample 402A-18-4, 75-78 cm. Ventral view; arrow indicates the small parasulcal meshes (phase contrast).

3. MPK 1736. Sample 402A-23-6, 35-38 cm. Lateral view (phase contrast).

4, 5. MPK 1693. Sample 400A-67-0. 4, Dorsolateral view; arrow indicates an elongate paracingular mesh situated above a large postcingular mesh. 5, Ventro-lateral view; arrow indicates the small parasulcal meshes.

Figure 6 Lecaniella foveata Singh. MPK 1726. Sample 402A-17-2, 119-122 cm.

Figure 7 Hystrichodinium dasys Davey. MPK 1758. Sample $402 \mathrm{~A}-35-1,108-111 \mathrm{~cm}$. Lateral view illustrating paracingular, pre- and postcingular paraplates.

Figures 8-12 Membranosphaera sp. A. Sample 400A-71-1, $111-113 \mathrm{~cm}$.

8. MPK 1703. Dorsal view.

9. MPK 1704. Dorsal view.

10. MPK 1705. Medial view; operculum attached.

11. MPK 1704. Detail of short bifurcating processes. $\times 1250$ (phase contrast).

12. MPK 1707. Ventral view.

Figures 13, 14 Histiocysta sp. A. MPK 1712. Sample 400A-72-3, $40-42 \mathrm{~cm}$.

14. Interference contrast.

Figure 15 Litosphaeridium conispinum Davey and Verdier. MPK 1663. Sample 400A-62-2, 41-43 cm. Medial view illustrating subconical paracingular processes.

Figures 16, 17 Litosphaeridium arundum (Eisenack and Cookson). Sample CP21/4, Copt Point, Folkestone, Kent. $M$. inflatum Zone.

16. Ventral view. Operculum attached.

17. Dorsal view. Operculum attached.

Figure 18 Chlamydophorella huguonioti (Valensi). MPK 1667.

Sample 400A-62-4, 111-113 cm. 
PLATE 4

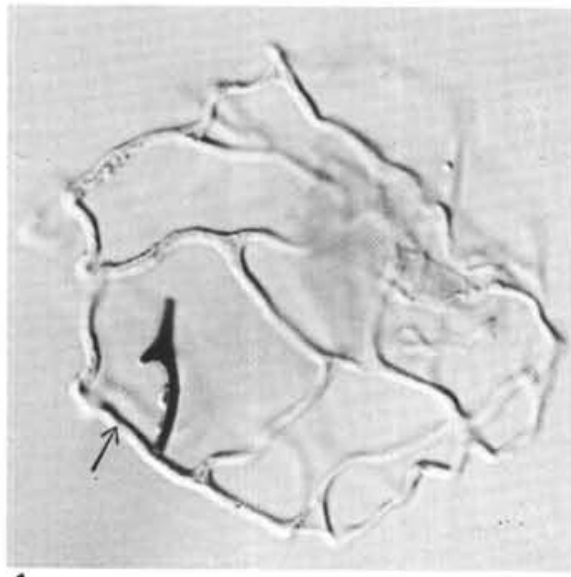

1
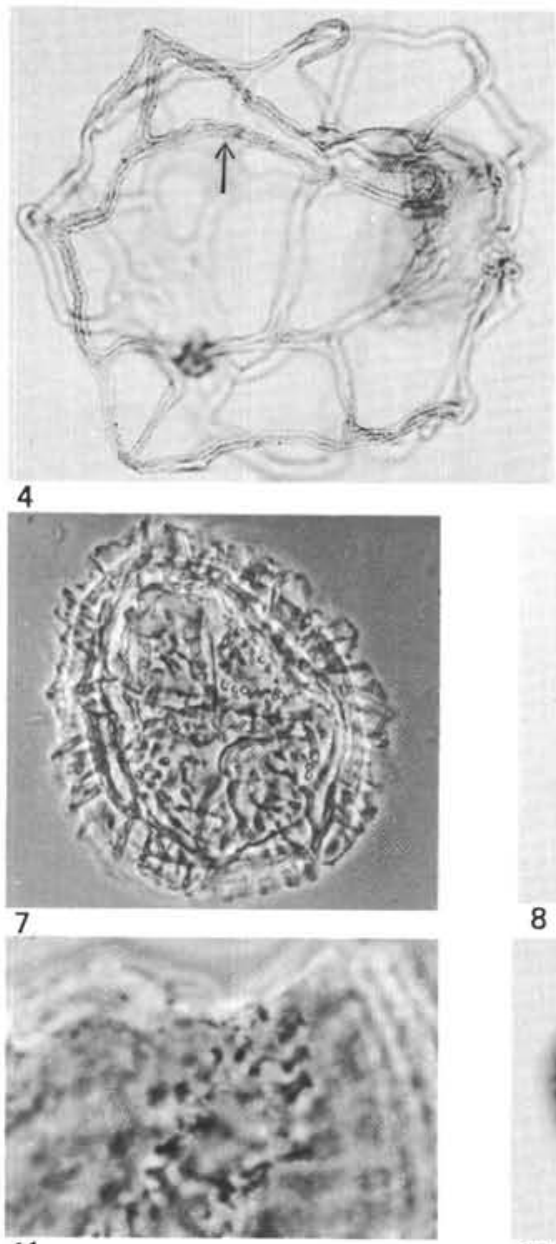

11

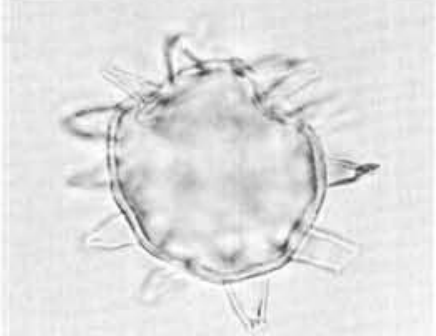

15

8

12

16
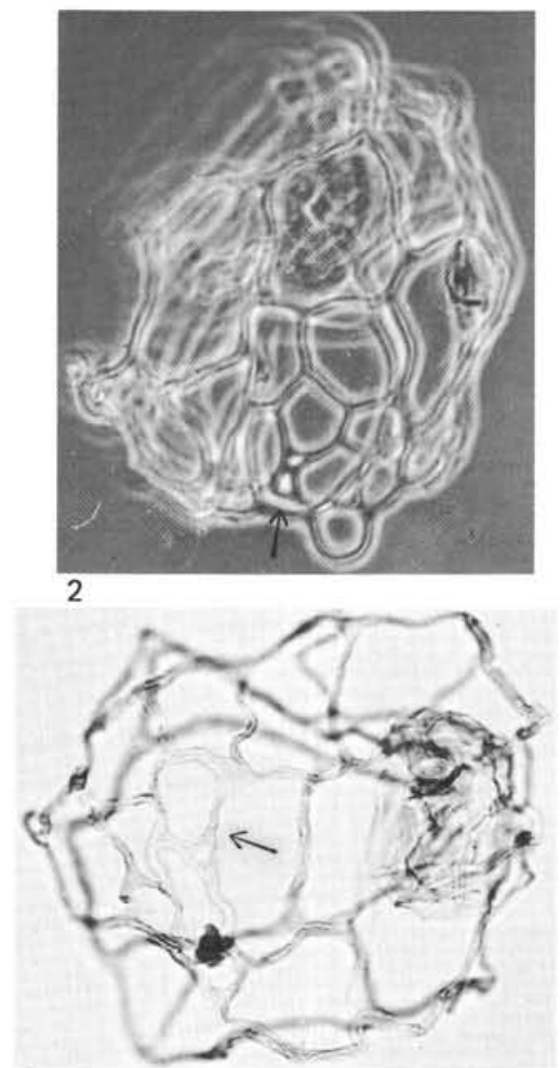

5
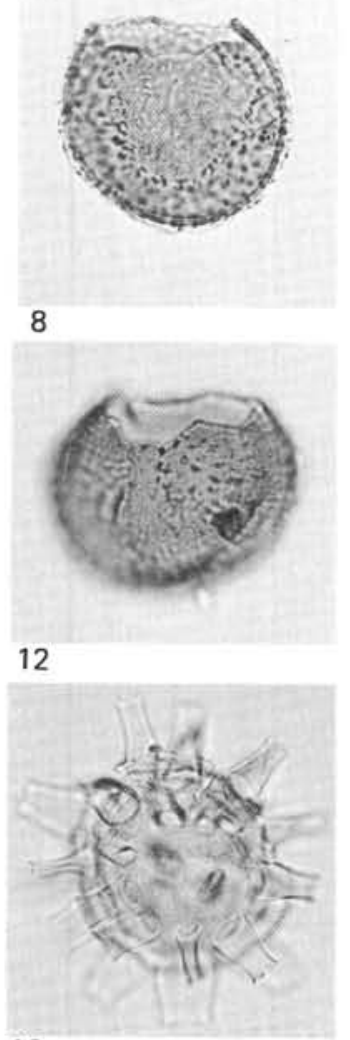

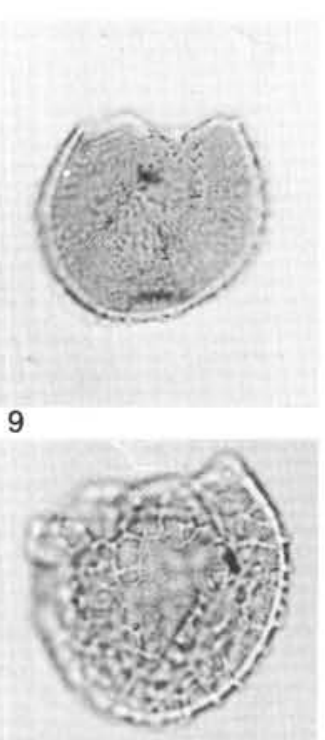

13

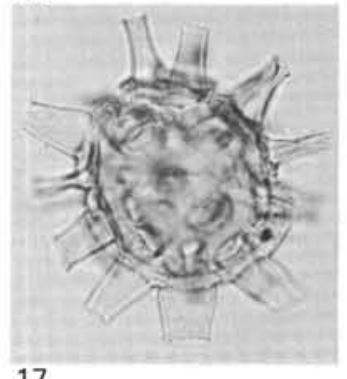

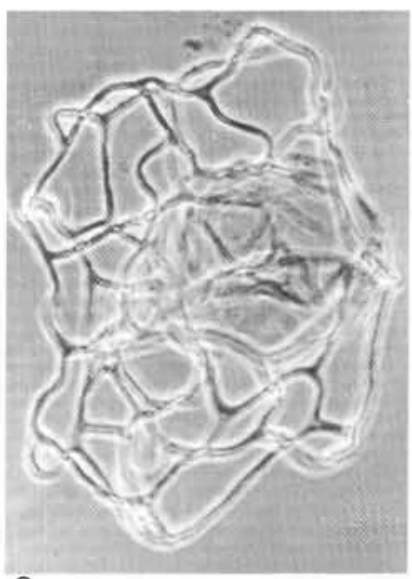

3



6
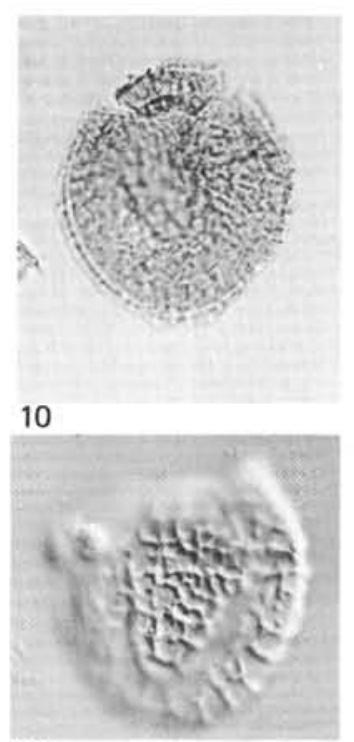

14

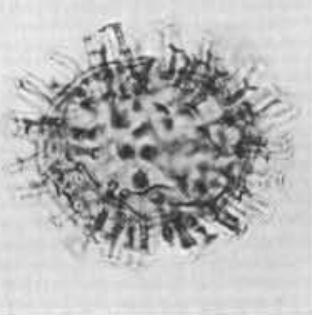

18 


\section{PLATE 5}

(Magnification $\times 500$ unless otherwise stated.)

Figures 1-3 Oligosphaeridium verrucosum $\mathrm{sp}$. nov.

1, 2. Holotype. 1, Ventral view; arrow indicates bald precingular paraplate boundary. 2, Dorsal view.

3. MPK 1701. Sample 400A-70-0. Detached operculum; note the elongate first apical paraplate $\left(1^{\prime}\right)$.

Figures 4, $5 \quad$ Muderongia cf. staurota Sarjeant.

4. MPK 1753. Sample 402A-31-6, 15-19 cm.

5. MPK 1749. Sample 402A-30-6, 60-63 cm.

Figures $6,10,14$ Nematosphaeropsis singularis sp. nov.

14

6. MPK 1730. Sample 402A-19-4, 81-84 cm (phase contrast).

10. MPK 1743. Sample 402A-26-1, 9-14 cm.

14. Holotype (interference contrast).

Figures 7-9, Ovoidinium implanum sp. nov. Sample 400A-62-4, $11,12 \quad 111-113 \mathrm{~cm}$.

7, 11. Holotype. 7, Ventral view. 11, Ventral hypocyst illustrating reduced pericoel. $\times 1250$ (phase contrast).

8. MPK 1669. Dorsal view; operculum partially attached (phase contrast).

9. MPK 1670 (phase contrast).

12. MPK 1671 (complete specimen).

Figure 13 Eyrea nebulosa Cookson and Eisenack. MPK 1713. Sample 400A-72-3, 40-42 cm. 


\section{PLATE 5}
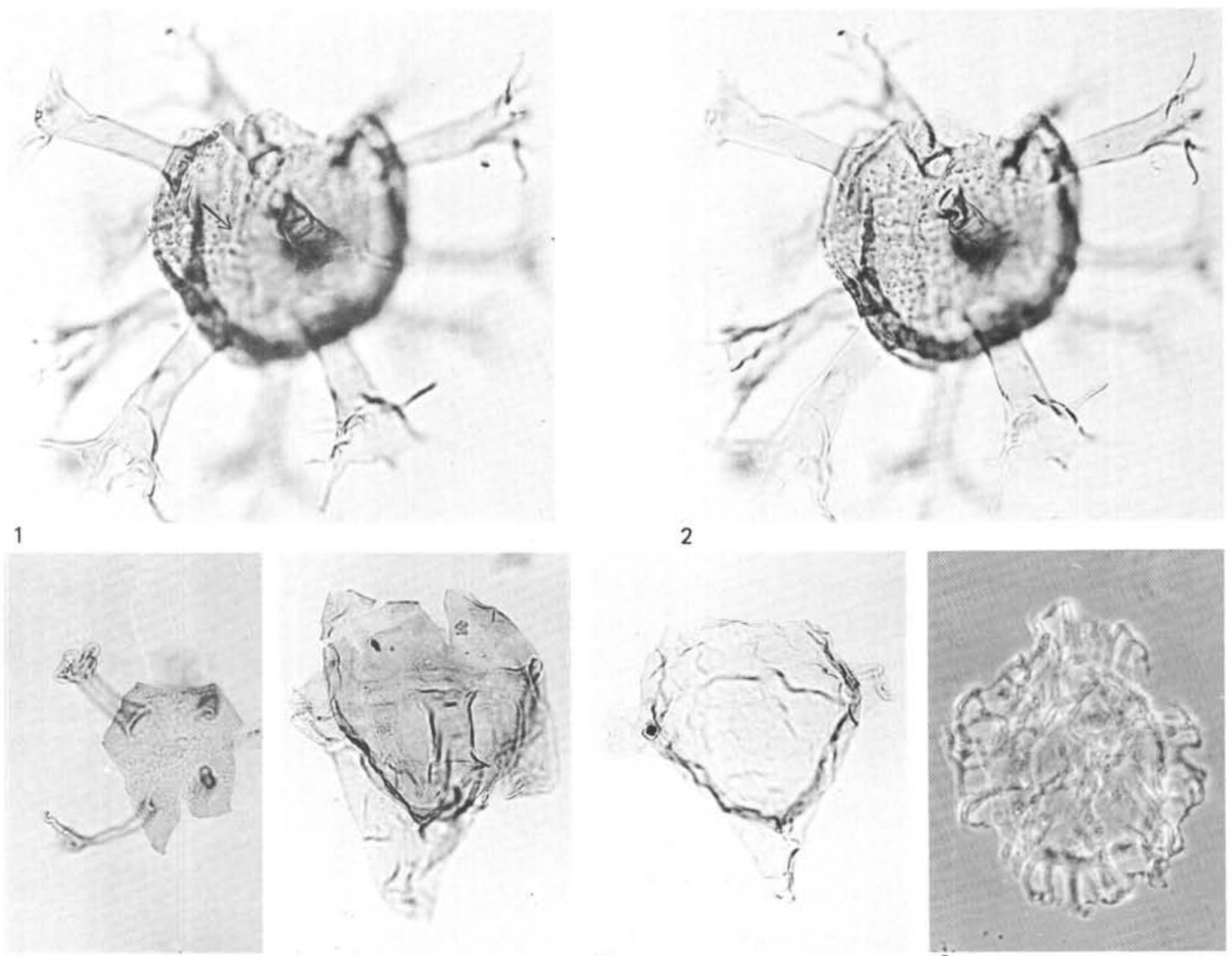

3

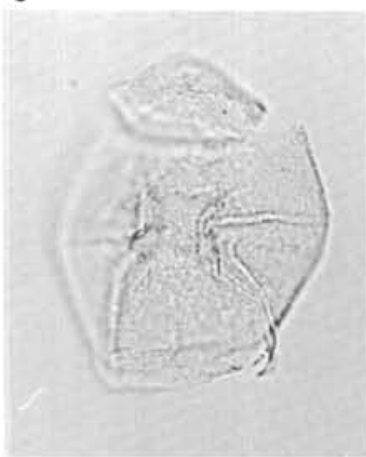

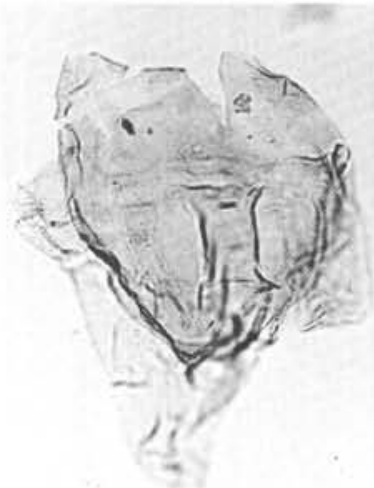

4
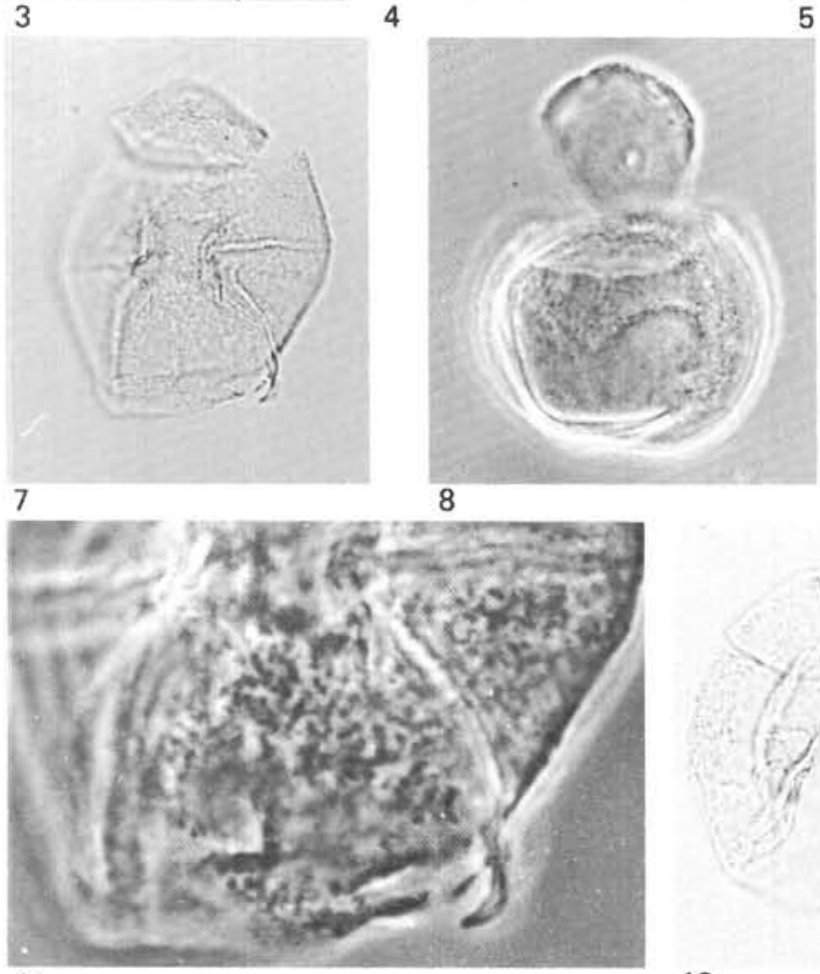

11



12

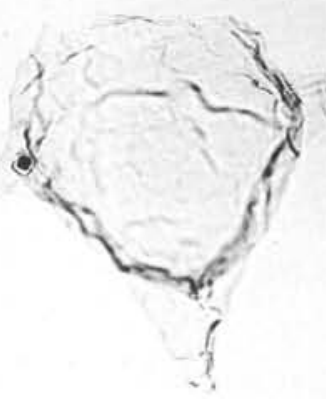

5
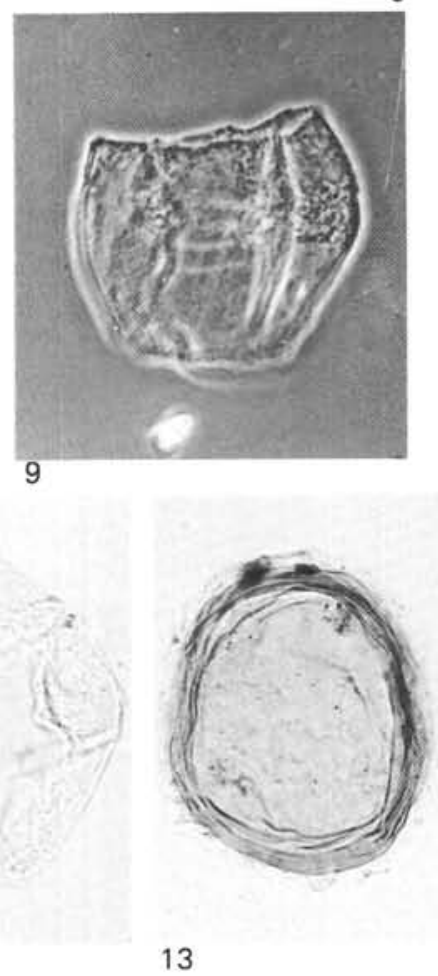

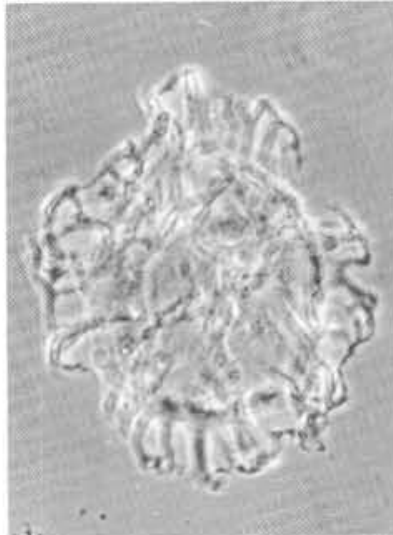

6

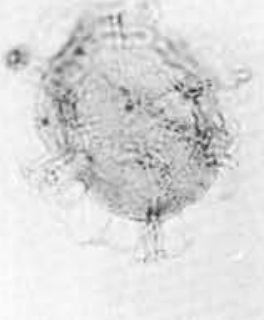

10

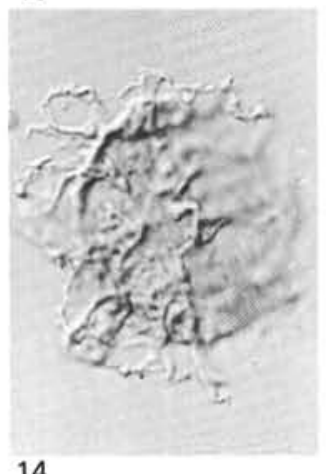


PLATE 6

(Magnification $\times 500$ unless otherwise stated.)

Figures 1-5 Nexosispinum hesperum sp. nov.

1. MPK 1727. Sample 402A-17-2, 119-122 cm. Detail of anastomozing spines. $\times 1250$ (phase contrast).

2. MPK 1725. Sample 402A-16-2, 34-37 cm. Process alignment. $\times 1250$ (phase contrast).

3, 4. MPK 1718. Sample 400A-74-1, 4-6 cm. 3, Antapical surface. 4, Apical-archeopyle surface.

5. Holotype. Dorsal surface with precingular (2P) archeopyle; arrow points to re-entrant angle of archeopyle.

Figures 6-16 Ovoidinium diversum sp. nov

6-8. Detached opercula. 6, MPK 1754. Sample 402A-31-6, 15-19 cm. Arrows indicate separation of delicate periphragm from the endophragm. 7, MPK 1689. Sample 402A-19-4, 81-84 cm. Boundaries between the individual apical and intercalary paraplates are shown. 8, MPK 1690. Sample $402 \mathrm{~A}-26-1,9-14 \mathrm{~cm}$. The periphragm is here loosely adhering to the individual opercular paraplates,

9. Holotype. Lateral view. Periphragm relatively closely adhering to the endophragm.

10. Paratype 1. Dorsal surface. Note large extensions of the periphragm above apical, antapical, preand postcingular paraplates. Arrow indicates the boundary between paraplates $2 \mathrm{a}$ and 4 ".

11. Paratype 2. Dorsal view. Periphragm closely adhering to the endophragm. Archeopyle developed; arrow pointing the $2 \mathrm{a}-4^{\prime \prime}$ paraplate boundary.

12. MPK 1741. Sample 402A-25-5, 5-8 cm. Apical view with operculum in place; arrow points to the $2 \mathrm{a}-4^{\prime \prime}$ paraplate boundary. Note apparent paraplate thickenings which sometimes occur.

13. MPK 1721. Sample 402A-13-2, 93-96 cm Apical view, operculum detached. Note wrinkling of periphragm.

14. MPK 1744. Sample 402A-26-1, 9-14 cm. Lateral view, operculum attached. Note very thick endophragm.

15. MPK 1722. Sample 402A-13-2, 93-96 cm. Medial view illustrating the nature of the periphragm.

16. MPK 1750. Sample 402A-30.6, 60-63 cm Dorsal view; archeopyle developed. Arrow indicates the boundary between paraplates $2 \mathrm{a}$ and $4 "$.

Figures 17-20 Ovoidinium sp. A. Sample 400A-72-3, 40-42 cm.

17. MPK 1714. Ventral view.

18. MPK 1715. Ventral view.

19, 20. MPK 1716. 19. Dorsal view. Note characteristic shape of paraplate $2 a$ of the operculum. 20. Ventral view. 


\section{PLATE 6}
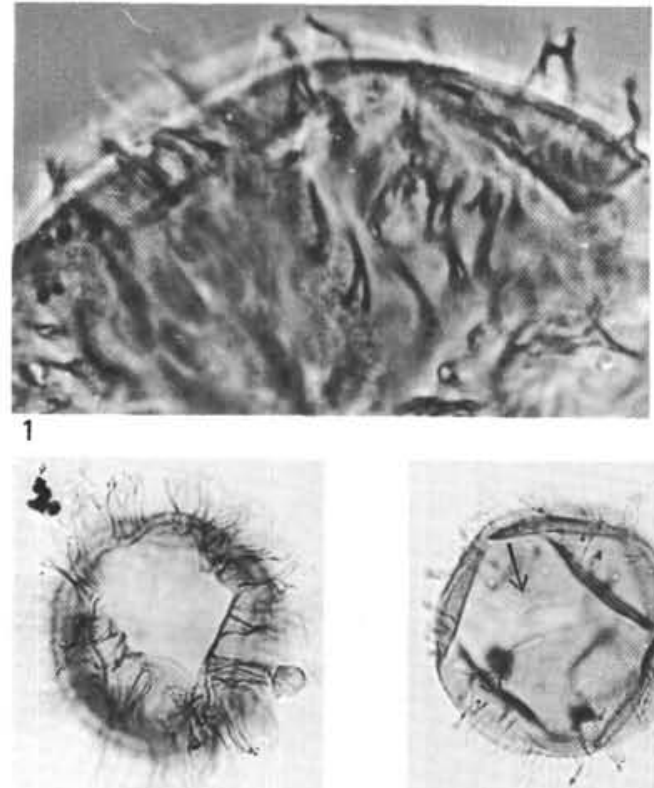

4



9

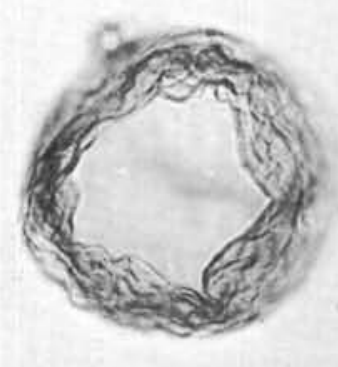

13

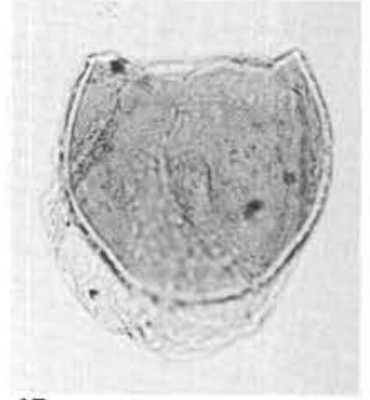

17

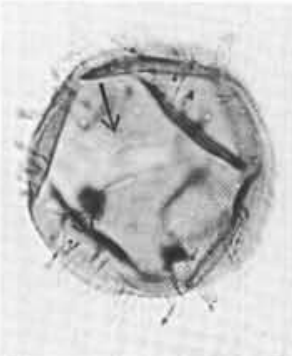

5
18



2

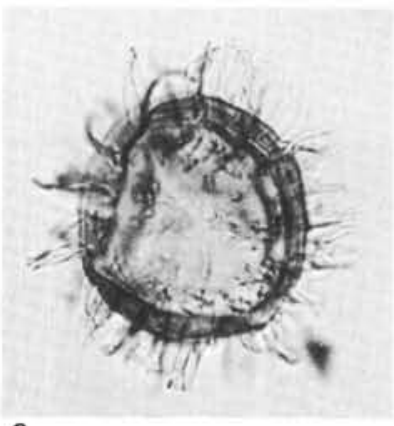

3
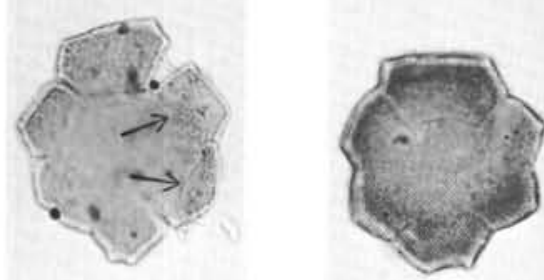

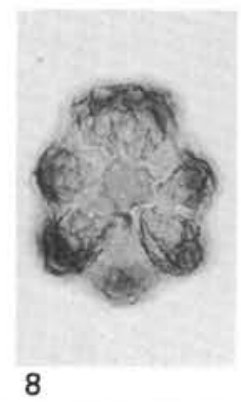

6

7

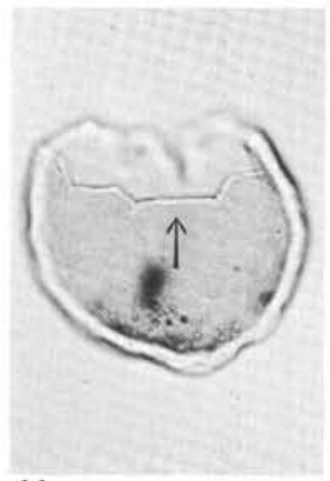

11

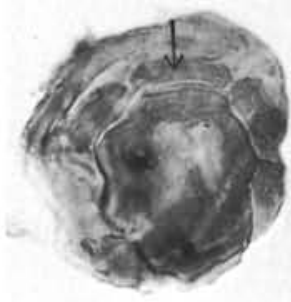

12


16
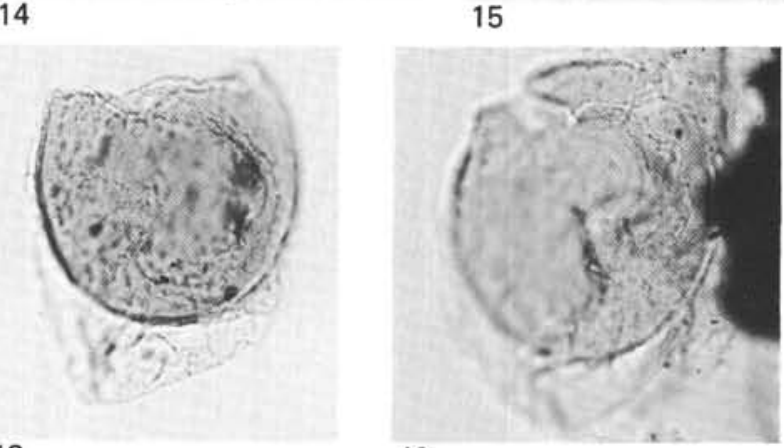

19

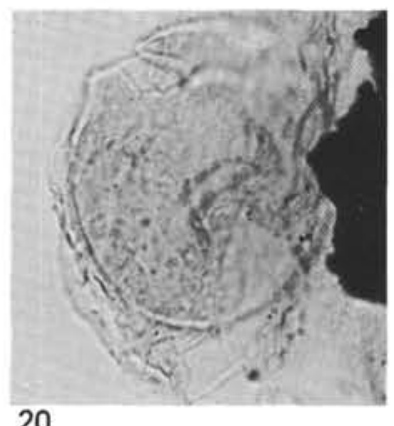


PLATE 7

(Magnification $\times 500$ unless otherwise stated.)

Figures 1, 4, 9 Polystephanephorus anthophorum (Cookson and Eisenack).

1, 4. MPK 1719. Sample 402A-11-4, 105-108 cm. 1, Apical view; archeopyle developed. The finer parasulcal processes are at the bottom. 4, Antapical view.

9. MPK 1724. Sample 402A-15-6, 23-26 cm. Detached operculum.

Figures 2, 3 Polysphaeridium pumilum Davey and Williams. MPK 1682. Sample 400A-64-3, 52-55 cm.

2,3 . Process terminations. $\times 1250$ (phase contrast).

Figures 5-7 Prolixosphaeridium parvispinum (Deflandre).

5. MPK 1708. Sample 400A-71-1, 111-113 cm.

6. MPK 1717. Sample 400A-72-3, 40-42 cm (interference contrast).

7. MPK 1760. Sample 402A-35-3, 69-72 cm (phase contrast).

Figures 8, 11 Spiniferites ramosus (Ehr.) subsp. reticulatus (Davey and Williams). MPK 1709. Sample 400A-71-1, $111-113 \mathrm{~cm} .8$, Lateral view. 11, Surface detail. $\times 1250$ (phase contrast).

Figure 10 Polysphaeridium laminaspinosum Davey and Williams. MPK 1672. Sample 400A-62-4, 111-113 $\mathrm{cm}$ (phase contrast).

Figure 12 Pterodinium cf. aliferum Eisenack. MPK 1686. Sample 400A-65-2, 19-22 cm. Lateral view.

Figures 13, 14 Pterodinium aliferum Eisenack.

13. MPK 1664. Sample 400A-62-2, 41-43 cm. Ventral view.

14. MPK 1710. Sample 400A-71-1, 111-113 cm. Medial view illustrating high, slightly serrate crests. 
PLATE 7


4
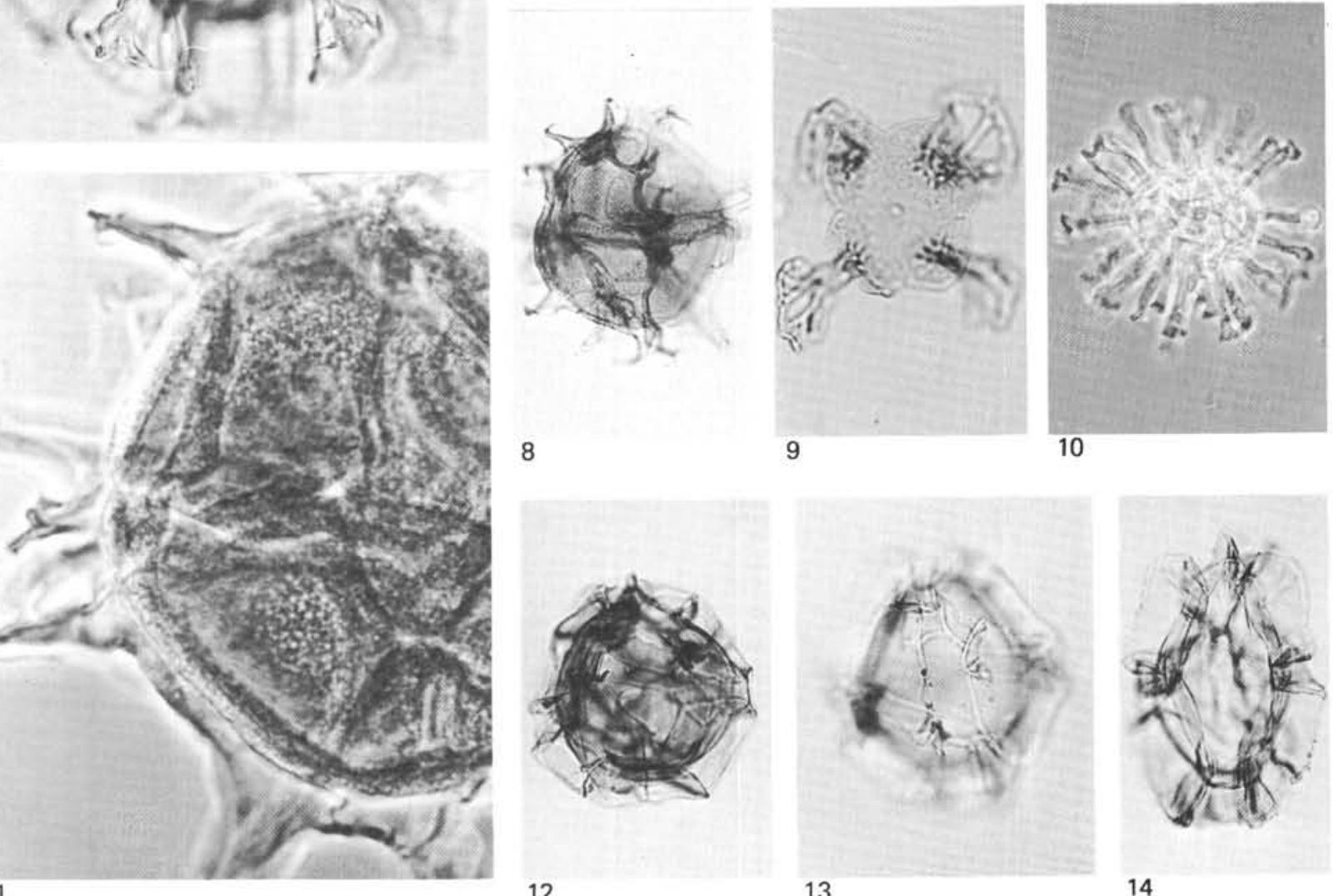

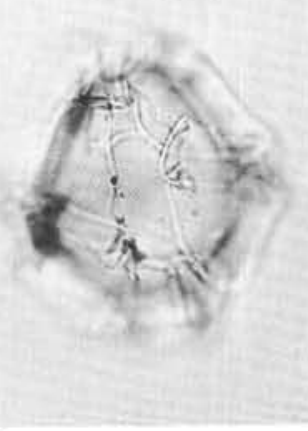

14 
PLATE 8

(Magnification $\times 500$ )

Figures 1-4 Spiniferites confossus sp. nov.

1-3. Holotype. 1, Dorsal view; precingular archeopyle developed. 2, Medial view. 3, Ventral view.

4. MPK 1746. Sample 400A-69-1, 84-86 cm.

Figure 5 Trichodinium sp. MPK 1733. Sample 402A-20-4, $7-10 \mathrm{~cm}$. Detached precingular operculum.

Figures 6-9 Surculosphaeridium trunculum sp. nov.

6. MPK 1751. Sample 402A-30-6, 60-63 cm. Lateral view; arrow indicates two fine paracingular processes developed on one cingular paraplate.

7. Holotype. Lateral view; arrows indicate basal furcations in precingular processes (interference contrast).

8. MPK 1752. Sample 402A-30-6, 60-63 cm. Lateral view; arrow indicates two fine paracingular processes linked by a bar.

9. MPK 1745. Sample 402A-26-1,9-14 cm. Lateral view.

Figures 10, 13- Systematophora cretacea sp. nov.

15

10, 13. Holotype. 10, Ventral view. 13, Dorsal view.

14. MPK 1684. Sample 400A-64-3, 52-55 cm. Detached operculum. Arrow indicates paraplate 2 ' which does not bear a process.

15. MPK 1691. Sample 400A-66-3, 55-60 cm. Detached operculum.

Figure 11 Subtilisphaera terrula (Davey). MPK 1731. Sample 402A-19-4, 81-84 cm. Lateral view; arrow indicates archeopyle breakage high on the epicyst (phase contrast).

Figure 12 Subtilisphaera perlucida (Alberti). MPK 1761. Sample 402A-35-3, 69-72 cm. Lateral view; arrow indicates archeopyle breakage in the intercalary region.

Figures 16, 17 Scolecodonts.

16. MPK 1728. Sample 402A-17-2, 119-122 cm.

17. MPK 1685. Sample 400A-64-3, $52-55 \mathrm{~cm}$. 
PLATE 8

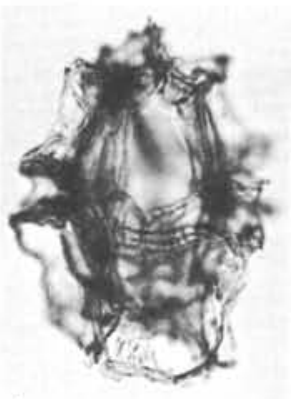

1
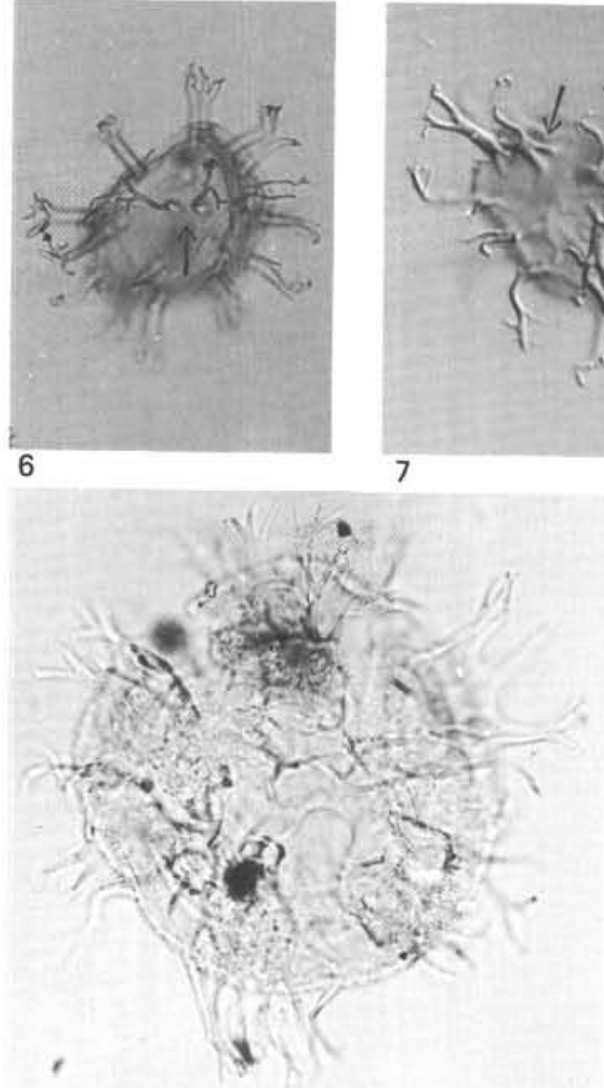

10



2
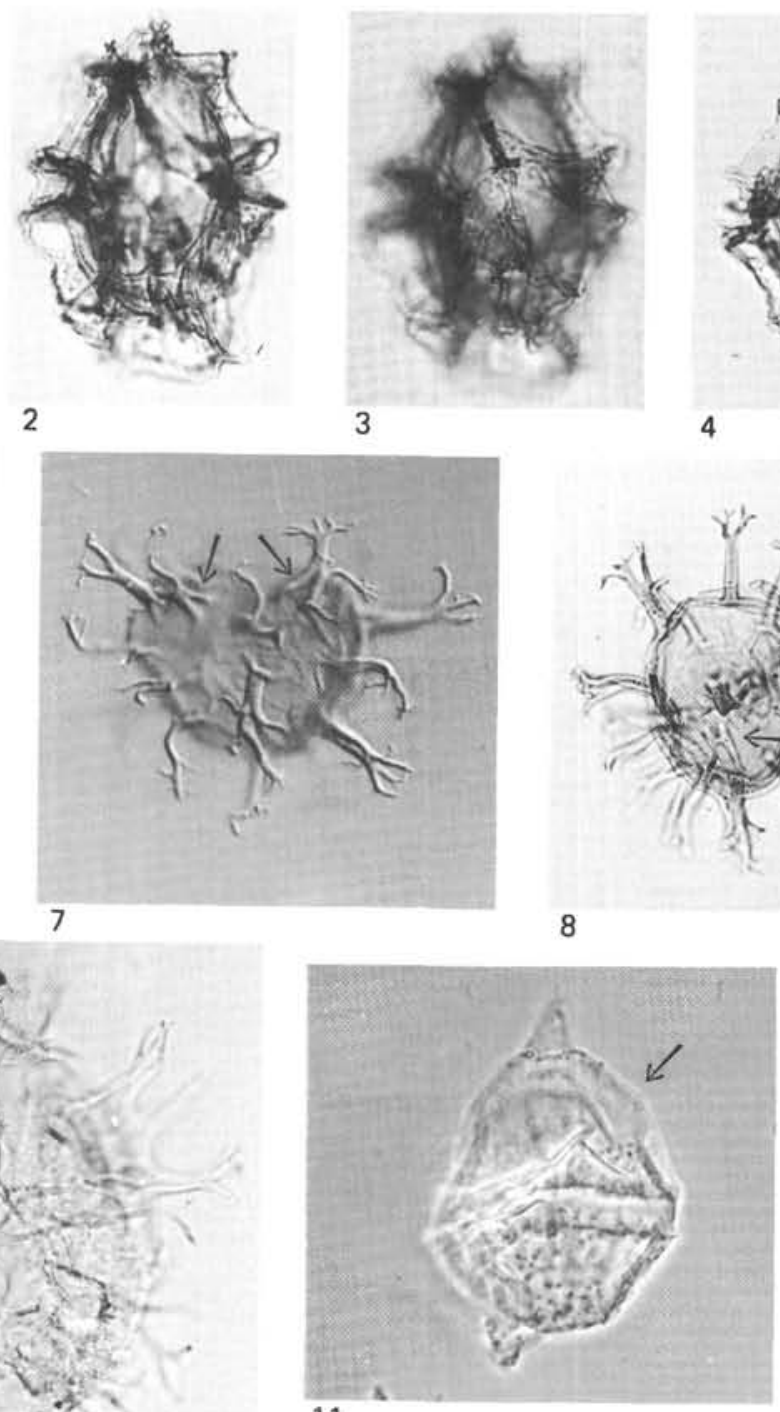

11

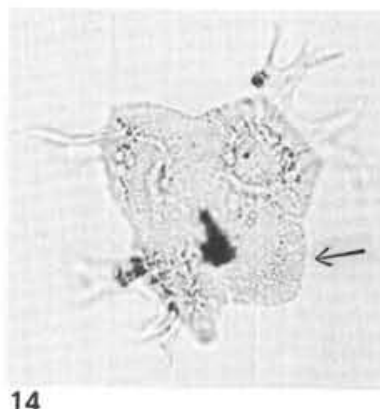

14

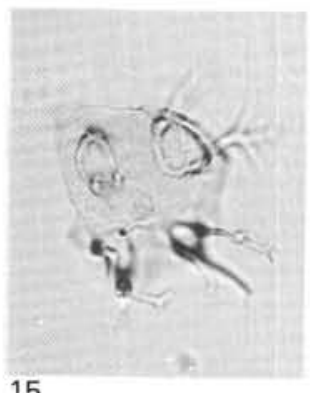

15
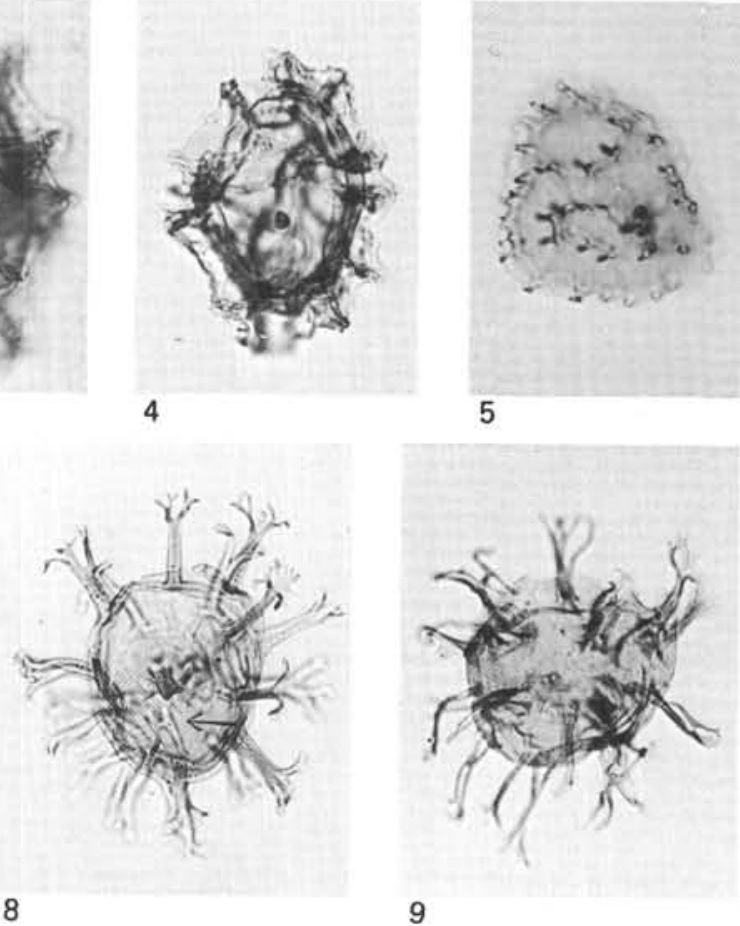

9

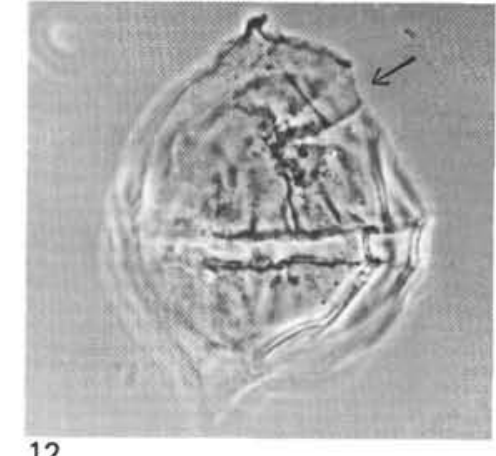

12
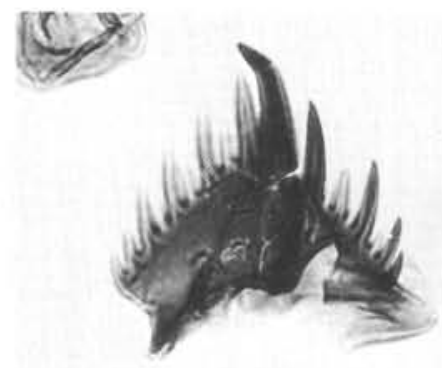

16



17 